\title{
Cell Therapy in Dermatology
}

\author{
Gabriela Petrof, Alya Abdul-Wahab, and John A. McGrath \\ St. John's Institute of Dermatology, King's College London (Guy's Campus), London SE1 1UL, \\ United Kingdom \\ Correspondence: john.mcgrath@kcl.ac.uk
}

Harnessing the regenerative capacity of keratinocytes and fibroblasts from human skin has created new opportunities to develop cell-based therapies for patients. Cultured cells and bioengineered skin products are being used to treat patients with inherited and acquired skin disorders associated with defective skin, and further clinical trials of new products are in progress. The capacity of extracutaneous sources of cells such as bone marrow is also being investigated for its plasticity in regenerating skin, and new strategies, such as the derivation of inducible pluripotent stem cells, also hold great promise for future cell therapies in dermatology. This article reviews some of the preclinical and clinical studies and future directions relating to cell therapy in dermatology, particularly for inherited skin diseases associated with fragile skin and poor wound healing.

$\mathrm{O}_{a}^{\mathrm{n}}$ ne of the key functions of skin is to provide a mechanical barrier against the external environment. In several inherited and acquired dermatological disorders, however, this resilience is broken. Loss of a functional epidermis can have profound biological and clinical consequences including loss of water and electrolytes, cutaneous and systemic infections, as well as impaired thermoregulation. Epidermal failure can occur from burns, trauma, and adverse drug reactions. Several inherited diseases associated with inherent mechanical weaknesses in epidermal or dermal structural proteins can all be associated with extensive skin wounds and chronic erosions. Ulceration of the skin caused by common pathologies such as venous hypertension, arterial impairment, diabetes mellitus, or neuropathies creates an enormous clinical and health economic burden. Therapeutic in- terventions to restore an intact epithelium and recover skin function have therefore been an important long-term focus of both traditional and translational medicine, and one in which a number of key advances and clinical benefits have occurred in recent years.

Cell therapy to repair or restore a defective epithelium and possibly deeper skin layers represents an attractive area of translational research that could have significant health benefits for many people. In this review, we discuss the development and application of cell therapy in dermatology, with a special focus on inherited skin disorders in which chronic ulceration has a major impact on quality of life. The main emphasis of the text is on recent clinical studies as well as new and emerging strategies that can exploit and harness the regenerative potential of human cells to restore skin tissue, although

Editors: Anthony E. Oro and Fiona M. Watt

Additional Perspectives on The Skin and Its Diseases available at www.perspectivesinmedicine.org

Copyright (C) 2014 Cold Spring Harbor Laboratory Press; all rights reserved; doi: 10.1101/cshperspect.a015156

Cite this article as Cold Spring Harb Perspect Med 2014;4:a015156 
G. Petrof et al.

an overview of the clinical applications of cell therapy across a range of skin diseases is presented in Table 1. With regard to the focus of this review, it is hoped that cell therapy lessons learned from studies on rare skin diseases will also be relevant to improving future healthcare of patients with more common disorders associated with defective skin.

\section{KERATINOCYTE CULTURE AND SKIN GRAFTING}

In 1975, the discovery by Rheinwald and Green (1975) that keratinocytes could be cultured in vitro and the subsequent work that showed the enzyme dispase could help create sheets of cells suitable for grafting (Green et al. 1979) led to radical new options for clinical translation, including the treatment of burns patients (O'Connor et al. 1981). Notably, a small piece of skin $\left(\sim 2 \mathrm{~cm}^{2}\right)$ could be grown into sheets of epithelium, or cultured keratinocyte grafts that were suitable for treating wounds. Serial subculture enabled rapid expansion of the keratinocytes, such that grafts of a total area equivalent to that of the surface of an adult could be obtained in $<1$ mo. Thereafter, the development of composite skin grafts, including a dermal component such as de-epidermized cadaveric dermis, biopolymers, or artificial scaffolds allowed for further refinement of cultured skin for clinical use (Ojeh et al. 2001; Auger et al. 2004). Cultured epidermal grafts have been shown to promote re-epithelialization in some genetic skin diseases associated with chronic wounds (Schofield et al. 1990; Hill et al. 1992; McGrath et al. 1993; Roseeuw et al. 1994), although success has been limited mainly because of the high risk of graft infection.

Newer devices, including cell spray formulations (following digestion of small pieces of skin with trypsin) that can contain keratinocytes, melanocytes, Langerhans cells, and fibroblasts have also been developed (Gravante et al. 2007) and used in clinical trials to augment wound healing (Kirsner et al. 2012). In addition, the use of noncutaneous cells, such as bone marrow (BM) cells, has been explored in skin regeneration, particularly with a view of treating the entire skin (and possibly mucous membranes) rather than limited areas of damaged skin (Wagner et al. 2010).

\section{INHERITED SKIN DISEASES AND THE NEED FOR INNOVATIVE THERAPIES}

Epidermolysis bullosa (EB) refers to a group of inherited skin disorders in which blisters develop after relatively minor trauma to the skin. EB results from mutations in at least 18 different genes, mostly encoding structural components of the dermal-epidermal junction (DEJ) or keratinocytes within the lower epidermis (Fine et al. 2008). Although EB is a rare disease, with an estimated incidence of 1 in 20,000 people, this equates to a worldwide incidence of approximately 500,000 individuals. Collectively, this population has a desperate need for innovative therapies that reduce disease burden, improve quality of life, and make advances toward a cure. In some forms of $\mathrm{EB}$, such as recessive dystrophic epidermolysis bullosa (RDEB), there may be very extensive fragility of the skin and mucous membranes. This profound skin fragility can be associated with delayed wound healing and persistent erosions with longer term complications of scarring and increased incidence of malignancy (Fine and Mellerio 2009a,b). Recently, considerable progress has been made in developing new treatments for EB, including gene, protein, and drug therapy, although cell therapies have perhaps shown the most clinical translation (Uitto et al. 2012). The major challenge is to restore an intact epithelium and provide some protection against mechanical trauma. To that end, therapeutic use of autologous or allogeneic cells, used locally or systemically, is now being explored in clinical trials.

\section{MURINE STUDIES OF FIBROBLAST CELL THERAPY FOR EB}

Most murine studies have focused on developing therapies for RDEB in which the underlying pathology involves mutations in the COL7A1 gene encoding type VII collagen (C7), the major structural component of anchoring fibrils at the DEJ. C7 is synthesized and secreted by basal 


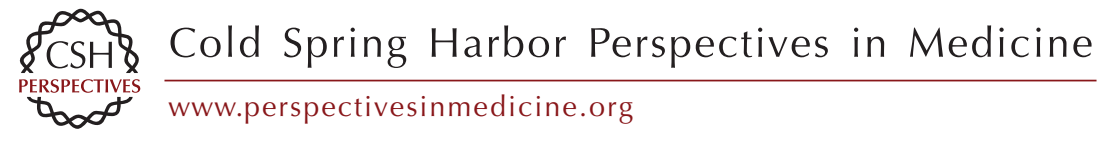

Table 1. Summarizing the clinical use of cell-based products to treat defective skin

\begin{tabular}{|c|c|c|c|c|c|c|}
\hline Cell type & Study type & Indication & Patient numbers & Components & Effect on wound healing & References \\
\hline \multicolumn{7}{|c|}{ Allogeneic epidermal graft } \\
\hline Keratinocyte & Case report & Burns & 3 & Cultured epidermal allograft & $\begin{array}{l}\text { Healed and remained } \\
\text { healthy for } 9-\mathrm{mo} \\
\text { follow up }(\mathrm{f} / \mathrm{u})\end{array}$ & Hefton et al. 1983 \\
\hline Keratinocyte & $\begin{array}{l}\text { Single-center } \\
\text { interventional } \\
\text { study }\end{array}$ & Burns & 26 & Cultured epidermal allograft & $\begin{array}{l}\text { Healed in } 7 \mathrm{~d} \\
\text { compared with } \\
14 \mathrm{~d} \text { (control } \\
\text { sites) }\end{array}$ & Madden et al. 1986 \\
\hline Keratinocyte & Case report & Adult RDEB & 1 & $\begin{array}{l}\text { Cultured allogeneic } \\
\text { keratinocyte graft applied } \\
\text { to nonhealing wounds } \\
\text { (>3-mo duration) }\end{array}$ & $\begin{array}{l}\text { Wounds re-epithelized } \\
\text { after } 7 \mathrm{~d} \text {; no site } \\
\text { blistering for } 4 \mathrm{mo} \\
\text { postgraft }\end{array}$ & McGuire et al. 1987 \\
\hline Keratinocyte & Case report & TEN & 1 & $\begin{array}{l}\text { Cryopreserved epidermal } \\
\text { allograft applied to } \\
\text { pediatric case of drug- } \\
\text { induced TEN }\end{array}$ & $\begin{array}{l}\text { Viable graft; healing } \\
\text { epidermis appeared } \\
\text { normal }\end{array}$ & Birchall et al. 1987 \\
\hline Keratinocyte & Prospective study & RDEB & 6 & $\begin{array}{l}\text { Cultured epidermal } \\
\text { keratinocytes applied to } \\
\text { graft sites }\end{array}$ & $\begin{array}{l}\text { 4/6 healed before } \\
\text { controls; no } \\
\text { difference in C7 levels }\end{array}$ & Schofield et al. 1990 \\
\hline Keratinocyte & Case report & JEB-non-Herlitz & 1 & $\begin{array}{l}\text { Cultured epidermal allografts } \\
\text { applied to chronic central } \\
\text { facial erosions }\end{array}$ & $\begin{array}{l}\text { Re-epithelialization } \\
\text { over the course of } \\
\text { four graft procedures }\end{array}$ & Hill et al. 1992 \\
\hline Keratinocyte & $\begin{array}{l}\text { Multicenter } \\
\text { interventional } \\
\text { nonblinded } \\
\text { prospective study }\end{array}$ & Chronic venous ulcers & 21 & $\begin{array}{l}\text { Cryopreserved cultured } \\
\text { epidermal allografts }\end{array}$ & $\begin{array}{l}\text { 20/30 ulcers healed } \\
\text { completely within } \\
6 \mathrm{wk}\end{array}$ & De Luca et al. 1992 \\
\hline Keratinocyte & RCT & Chronic venous ulcers & 42 & $\begin{array}{l}\text { Cryopreserved cultured } \\
\text { epidermal allografts } \\
\text { compared with } \\
\text { hydrocolloid dressings }\end{array}$ & $\begin{array}{l}\text { No difference in healed } \\
\text { ulcers between two } \\
\text { groups }\end{array}$ & Teepe et al. 1993 \\
\hline
\end{tabular}




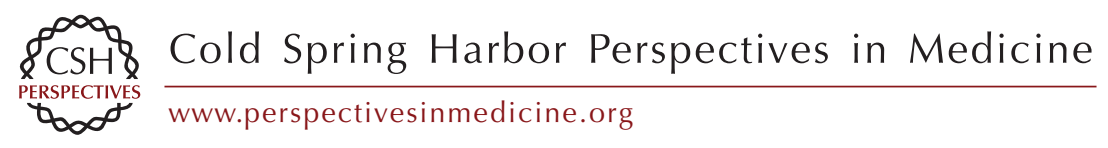

Table 1. Continued

\begin{tabular}{|c|c|c|c|c|c|c|}
\hline Cell type & Study type & Indication & Patient numbers & Components & Effect on wound healing & References \\
\hline Keratinocyte & $\begin{array}{l}\text { Interventional } \\
\text { prospective study }\end{array}$ & Adult RDEB & 10 & $\begin{array}{l}\text { Cultured allogeneic } \\
\text { keratinocyte graft applied } \\
\text { to dermatome-induced } \\
\text { superficial wounds; } \\
\text { compared with nongrafted } \\
\text { sites }\end{array}$ & $\begin{array}{l}\text { Little benefit detected } \\
\text { compared with } \\
\text { nongrafted sites }\end{array}$ & McGrath et al. 1993 \\
\hline Keratinocyte & Case report & Pediatric JEB-Herlitz & 1 & $\begin{array}{l}\text { Cultured epidermal allograft } \\
\text { applied to open wounds in } \\
\text { a neonate }\end{array}$ & $\begin{array}{l}\text { Significant } \\
\text { epithelialization } 70 \% \\
\text { of wounds; new } \\
\text { lesions continued to } \\
\text { develop }\end{array}$ & Roseeuw et al. 1994 \\
\hline Keratinocyte & $\begin{array}{l}\text { Randomized } \\
\text { controlled trial }\end{array}$ & $\begin{array}{l}\text { Burns (deep partial } \\
\text { thickness and donor } \\
\text { sites) }\end{array}$ & 15 & $\begin{array}{l}\text { Cultured epidermal allograft } \\
\text { compared with control } \\
\text { dressings }\end{array}$ & $\begin{array}{l}\text { Improved } \\
\text { epithelialization } \\
\text { compared with } \\
\text { control ( } 6 \text { d vs. } 11 \text { d) }\end{array}$ & $\begin{array}{l}\text { Rivas-Torres et al. } \\
1996\end{array}$ \\
\hline Keratinocyte & $\begin{array}{l}\text { Prospective } \\
\text { interventional } \\
\text { study }\end{array}$ & Giant congenital naevi & 5 & $\begin{array}{l}\text { Cryopreserved epidermal } \\
\text { allograft or autologous } \\
\text { cultured epithelium } \\
\text { applied to lesions excised to } \\
\text { adipose tissue of children } \\
\text { with giant naevi ( } 10 \%- \\
52 \% \text { surface area) }\end{array}$ & $\begin{array}{l}3 / 5 \text { wounds healed well; } \\
2 / 5 \text { graft did not take; } \\
\text { vigorous rejection } \\
\text { reaction }\end{array}$ & Kumagai et al. 1997 \\
\hline Keratinocyte & Case report & RDEB & 1 & $\begin{array}{l}\text { Autologous meshed split- } \\
\text { thickness skin graft }+ \\
\text { allogeneic cultured } \\
\text { keratinocytes }\end{array}$ & $\begin{array}{l}\text { Reduction in pruritus; } \\
\text { blister-free at } \\
3 \mathrm{mo} \mathrm{f} / \mathrm{u}\end{array}$ & Verplancke et al. 1997 \\
\hline Keratinocyte & Prospective study & RDEB & 7 & $\begin{array}{l}\text { Composite cultured skin } \\
\text { allograft used in hand } \\
\text { surgery on children with } \\
\text { RDEB }\end{array}$ & $\begin{array}{l}\text { Average time to } \\
\text { recurrence was } \\
\text { increased by } \\
\text { approximately } \\
\text { twofold }\end{array}$ & $\begin{array}{l}\text { Eisenberg and } \\
\text { Llewelyn } 1998\end{array}$ \\
\hline
\end{tabular}




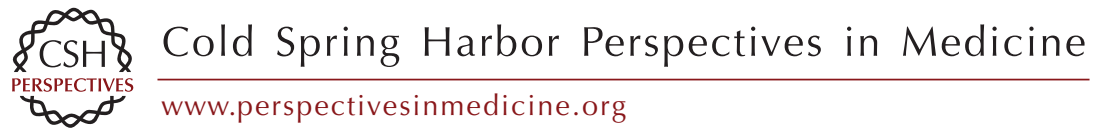

Keratinocyte RCT

$\begin{array}{ll}\text { Keratinocyte } & \text { Single-center } \\ & \text { interventional } \\ \text { study }\end{array}$

Keratinocyte Case report

Keratinocyte

Case report

\section{Autologous epidermal graft}

$\begin{array}{ll}\text { Keratinocyte } & \text { Case report } \\ \text { Keratinocyte } & \text { Single-center } \\ & \begin{array}{l}\text { interventional } \\ \text { study }\end{array}\end{array}$

Keratinocyte Case reports

Keratinocyte Case report

Keratinocyte

Multicenter retrospective experience

retrospective
experience

Burns

Burns (partial thickness)

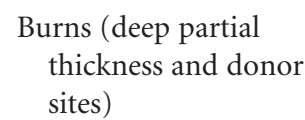
sites

Cutaneous GvHD following HSCT

Pediatric EBS

Burns

Vitiligo

JEB-non-Herlitz

Burns (partial and full thickness)
Cryopreserved cultured epidermal allografts applied to wounds in children

Cryopreserved cultured
epidermal allograft
Cryopreserved cultured
epidermal allografts
applied to wounds in
children

Cultured allogeneic

to nonhealing eroded

lesions

Cultured autologous epidermal graft
Cultured epidermal allograft (taken from HSCT donor)

keratinocyte graft applied

Autologous epidermal sheet grafted onto superficially dermabraded vitiliginous area

Cultured autologous epidermal graft applied to freshly excised wound bed or granulation tissue in children $>95 \%$ full thickness burn

Cultured epidermal autograft applied with $2 \%$ mupirocin ointment to facial wounds
Cultured epidermal autograft and allograft

\section{Accelerated}

re-epithelialization of 2000

deep $(n=9)$ and

superficial $(n=2)$

wounds

Mostly comparable in Yanaga et al. 2001

donor sites,

improved

epithelialization time

in deep partial

thickness burns

90\% of wounds healed Milner et al. 2011

by day 21

postoperative

Rapid

re-epithelialization

and wound healing

Shin et al. 2011

Grafts survived for the $8 \mathrm{mo} \mathrm{f} / \mathrm{u}$

Incomplete clinical

repigmentation in

$3 / 4$ patients at $4 \mathrm{wk}$

Successful engraftment; Gallico et al. 1984 $60 \%-80 \%$ of grafts

take when applied to

healthy granulation

tissue

\section{$/ 3$ showed}

re-epithelialization

after $7-10 \mathrm{~d}$

Carter et al. 1987

in children; $28 \%$

mean take in adults 


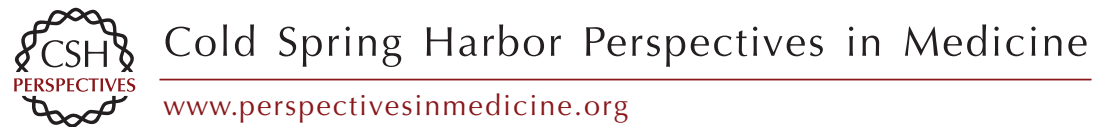

Table 1. Continued

\begin{tabular}{|c|c|c|c|c|c|c|}
\hline Cell type & Study type & Indication & Patient numbers & Components & Effect on wound healing & References \\
\hline Keratinocyte & $\begin{array}{l}\text { Single-center } \\
\text { interventional } \\
\text { study }\end{array}$ & Burns & 17 & Cultured epithelial autograft & $\begin{array}{l}\text { Improved graft take } \\
\text { compared with } \\
\text { untreated ( } 47 \% \text { vs. } \\
15 \%)\end{array}$ & Teepe et al. 1990 \\
\hline Keratinocyte & $\begin{array}{l}\text { Single-center } \\
\text { retrospective } \\
\text { review }\end{array}$ & Burns & 30 & $\begin{array}{l}\text { Cultured epithelial autograft } \\
\text { (Epicel) }\end{array}$ & $\begin{array}{l}\text { Good engraftment of } \\
\text { CEA and } 90 \% \\
\text { survival in severely } \\
\text { burned }\end{array}$ & Carsin et al. 2000 \\
\hline Keratinocyte & & RDEB & & & & \\
\hline Keratinocyte & $\begin{array}{l}\text { Multicenter } \\
\text { retrospective } \\
\text { analysis }\end{array}$ & Burns & 240 & $\begin{array}{l}\text { Cultured epithelial autograft } \\
\text { (Biosurface Technology, } \\
\text { Cambridge, MA) }\end{array}$ & $\begin{array}{l}64 \% \text { mean take of CEA } \\
\text { in } 104 \text { patients for } \\
\text { whom complete data } \\
\text { were available }\end{array}$ & Odessey 1992 \\
\hline Keratinocyte & $\begin{array}{l}\text { Review of } \\
\text { prospectively } \\
\text { collected database }\end{array}$ & Burns & 88 & $\begin{array}{l}\text { Cultured autologous } \\
\text { epidermal graft on a } \\
\text { cadaver allograft base }\end{array}$ & $\begin{array}{l}72.1 \% \text { final take rate of } \\
\text { graft in burns }>50 \% \\
\text { total surface area; } \\
91 \% \text { survival rate }\end{array}$ & Sood et al. 2010 \\
\hline Keratinocyte & $\begin{array}{l}\text { Phase I/II clinical } \\
\text { trial }\end{array}$ & JEB-non-Herlitz & 1 & $\begin{array}{l}\text { Genetically corrected cultured } \\
\text { epidermal graft transduced } \\
\text { using a retroviral vector } \\
\text { encoding } L A M B 3 \mathrm{cDNA} \\
\text { applied graft site prepared } \\
\text { using timed surgery }\end{array}$ & $\begin{array}{l}\text { Stable adherent } \\
\text { epidermis at } \\
12 \mathrm{mo} \mathrm{f} / \mathrm{u} \text {; } \\
\text { regenerated } \\
\text { epidermis contained } \\
\text { normal levels of } \\
\text { LAM5- } \beta 3\end{array}$ & Mavilio et al. 2006 \\
\hline Keratinocyte & $\begin{array}{l}\text { Retrospective } \\
\text { clinical audit }\end{array}$ & Burns ( $>50 \%$ TBSA) & $\begin{array}{l}84 \text { (only } \\
62 \text { treated) }\end{array}$ & $\begin{array}{l}\text { Spray on cultured autologous } \\
\text { cell suspension (Cellspray) } \\
\text { and autologous sheets }\end{array}$ & $\begin{array}{l}\text { Cell suspension } \\
\text { decreased mean } \\
\text { number of days to } \\
\text { first use of CEA }\end{array}$ & Wood et al. 2006 \\
\hline Keratinocyte & $\begin{array}{l}\text { Single-center } \\
\text { retrospective } \\
\text { audit }\end{array}$ & Burns (full thickness) & 16 & $\begin{array}{l}\text { Spray on cultured epithelial } \\
\text { autograft (Keraheal) } \\
\text { combined with } 6: 1 \text { mesh } \\
\text { graft }\end{array}$ & $90 \%$ take rate at $8 \mathrm{wk}$ & Lee 2012 \\
\hline Keratinocyte & Prospective RCT & Skin graft donor sites & 45 & $\begin{array}{l}\text { Autologous keratinocyte } \\
\text { suspension }+ \text { platelet }\end{array}$ & $\begin{array}{l}\text { Reduced healing time } \\
\text { with keratinocyte } \\
\text { suspension }+ \text { platelet }\end{array}$ & Guerid et al. 2013 \\
\hline
\end{tabular}




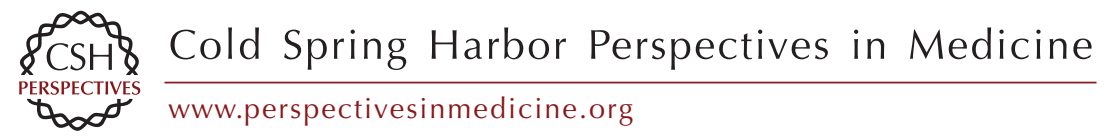

Table 1. Continued

\begin{tabular}{|c|c|c|c|c|c|c|}
\hline Cell type & Study type & Indication & Patient numbers & Components & Effect on wound healing & References \\
\hline $\begin{array}{r}\text { Melanocyte }+ \\
\text { keratinocyte }\end{array}$ & Pilot study & Vitiligo & 11 & $\begin{array}{l}\text { Melanocyte and keratinocyte } \\
\text { cell suspension }+ \\
\text { dermabrasion compared } \\
\text { with dermabrasion alone }\end{array}$ & $\begin{array}{l}\text { Minor improvement in } \\
\text { repigmentation } \\
\text { compared with } \\
\text { dermabrasion alone }\end{array}$ & $\begin{array}{l}\text { Vazquez-Martinez } \\
\text { et al. } 2011\end{array}$ \\
\hline \multicolumn{7}{|c|}{ Fibroblast cell therapy } \\
\hline Fibroblast & $\begin{array}{l}\text { Prospective pilot } \\
\text { study }\end{array}$ & $\begin{array}{l}\text { Prominent rhytid or facial } \\
\text { scar }\end{array}$ & 10 & $\begin{array}{l}\text { Intradermal cultured } \\
\text { autologous fibroblasts }\end{array}$ & $\begin{array}{l}\text { Size reduction between } \\
10 \%-85 \% \text {; } \\
\text { histologically } \\
\text { increased dermal } \\
\text { thickness }\end{array}$ & Watson et al. 1999 \\
\hline Fibroblast & $\begin{array}{l}\text { Prospective placebo- } \\
\text { controlled phase } \\
\text { III trial }\end{array}$ & $\begin{array}{l}\text { Facial contour } \\
\text { deformities }\end{array}$ & 215 & $\begin{array}{l}\text { Intradermal cultured } \\
\text { autologous fibroblasts }\end{array}$ & $\begin{array}{l}\text { Most significant } \\
\text { difference evident in } \\
\text { acne scars; continued } \\
\text { response rates up to } \\
12 \text { mo posttreatment }\end{array}$ & Weiss et al. 2007 \\
\hline Fibroblast & $\begin{array}{l}\text { Interventional } \\
\text { nonblinded } \\
\text { prospective study }\end{array}$ & Adult RDEB & 5 & $\begin{array}{l}\text { Intradermal injection } \\
\text { allogeneic cultured } \\
\text { fibroblasts; intact skin }\end{array}$ & $\begin{array}{l}\text { Increased COL7A1 and } \\
\mathrm{C} 7 \text { for } 3 \text { mo; can } \\
\text { remain raised for up } \\
\text { to } 9 \text { mo }\end{array}$ & $\begin{array}{l}\text { Wong et al. 2008; } \\
\text { Nagy et al. } 2011\end{array}$ \\
\hline Fibroblast & $\begin{array}{l}\text { Phase II placebo- } \\
\text { controlled } \\
\text { double-blind } \\
\text { RCT }\end{array}$ & Adult RDEB & 5 & $\begin{array}{l}\text { Intradermal cultured } \\
\text { allogeneic fibroblasts }\end{array}$ & $\begin{array}{l}\text { No significant } \\
\text { difference between } \\
\text { placebo; } \\
\text { improvement in QOL }\end{array}$ & Venugopal et al. 2013 \\
\hline Fibroblast & $\begin{array}{l}\text { Phase II double- } \\
\text { blind RCT }\end{array}$ & Adult RDEB & 11 & $\begin{array}{l}\text { Intradermal cultured } \\
\text { allogeneic fibroblasts into } \\
\text { wounded skin versus } \\
\text { vehicle }\end{array}$ & $\begin{array}{l}\text { Improvement in wound } \\
\text { healing noted up to } \\
28 \mathrm{~d}\end{array}$ & Petrof et al. 2013 \\
\hline Fibroblast & $\begin{array}{l}\text { Interventional } \\
\text { nonblinded study }\end{array}$ & Aging skin & 5 & $\begin{array}{l}\text { Intradermal cultured } \\
\text { autologous fibroblasts }\end{array}$ & $\begin{array}{l}\text { Benefits limited to slight } \\
\text { reduction in skin } \\
\text { fragility }\end{array}$ & Eca et al. 2012 \\
\hline Fibroblast & $\begin{array}{l}\text { Phase II open label } \\
\text { dose escalation } \\
\text { pilot study }\end{array}$ & Aging skin & 10 & $\begin{array}{l}\text { Intradermal cultured } \\
\text { allogeneic fibroblasts }\end{array}$ & $\begin{array}{l}\text { Slight reduction in } \\
\text { nasolabial crease }\end{array}$ & Lowe et al. 2010 \\
\hline
\end{tabular}




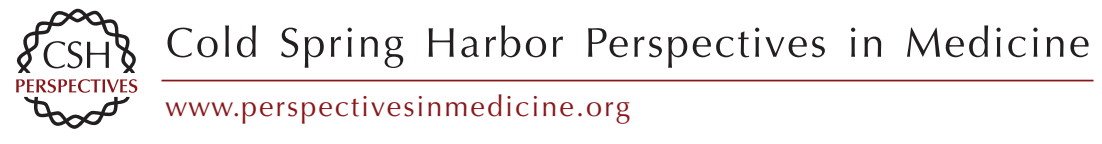

\begin{tabular}{|c|c|c|c|c|c|c|c|}
\hline 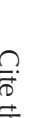 & Fibroblast & $\begin{array}{l}\text { Single-center } \\
\text { interventional } \\
\text { study }\end{array}$ & Aging skin and scars & 20 & $\begin{array}{l}\text { Intradermal cultured } \\
\text { autologous fibroblasts }\end{array}$ & $\begin{array}{l}\text { Variable improvement } \\
\text { at } 6 \mathrm{mo}\end{array}$ & $\begin{array}{l}\text { Nilforoushzadeh et al. } \\
2010\end{array}$ \\
\hline 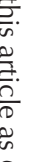 & $\begin{array}{l}\text { Keratinocyte } \\
\quad+\text { fibroblast }\end{array}$ & $\begin{array}{l}\text { Phase II placebo- } \\
\text { controlled } \\
\text { double-blind } \\
\text { RCT }\end{array}$ & Chronic venous ulcers & 205 & $\begin{array}{l}\text { Spray allogeneic neonatal } \\
\text { keratinocyte and fibroblast } \\
\text { cell-applied therapy }\end{array}$ & $\begin{array}{l}\text { Greater mean reduction } \\
\text { of wound size } \\
\text { compared with } \\
\text { placebo }\end{array}$ & Kirsner et al. 2012 \\
\hline 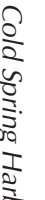 & Fibroblast & $\begin{array}{l}\text { Prospective } \\
\text { interventional } \\
\text { study }\end{array}$ & Burns (third degree) & 14 & $\begin{array}{l}\text { Allogeneic fibroblasts on } \\
\text { meshed split thickness skin } \\
\text { grafts }\end{array}$ & $\begin{array}{l}\text { Improved healing time } \\
\text { and hypertrophic } \\
\text { scar formation } \\
\text { compared with } \\
\text { conventional method }\end{array}$ & Moravvej et al. 2012 \\
\hline $\begin{array}{c}\frac{1}{2} \\
\frac{2}{2} \\
\frac{0}{2} \\
\frac{1}{2} \\
\frac{1}{2} \\
\frac{2}{2}\end{array}$ & Fibroblast & $\begin{array}{l}\text { Multicenter double- } \\
\text { blind placebo- } \\
\text { controlled phase } \\
\text { II RCT }\end{array}$ & Aging skin & 372 & $\begin{array}{l}\text { Intradermal cultured } \\
\text { autologous fibroblasts }\end{array}$ & $\begin{array}{l}\text { Moderate improvement } \\
\text { in nasolabial fold } \\
\text { wrinkles compared to } \\
\text { placebo; only } 1 \text { point } \\
\text { subjective difference }\end{array}$ & Smith et al. 2012 \\
\hline & \multicolumn{7}{|c|}{ Cultured dermal substitute } \\
\hline & CDS & $\begin{array}{l}\text { Prospective } \\
\text { interventional } \\
\text { study }\end{array}$ & RDEB & 3 & $\begin{array}{l}\text { Allogeneic cultured dermal } \\
\text { substitute using } \\
\text { cryopreserved normal } \\
\text { human fibroblasts on } \\
\text { matrix of hyaluronic acid } \\
\text { and Atelo-collagen }\end{array}$ & $\begin{array}{l}\text { Excessive granulation } \\
\text { found on wound } \\
\text { surface within } 1 \mathrm{wk} ; \\
\text { epithelialization at } \\
\text { margins of ulcer at } \\
4 \mathrm{wk}\end{array}$ & Hasegawa et al. 2004 \\
\hline & CDS & Case report & $\begin{array}{l}\text { Digital gangrene } \\
\text { associated } \\
\text { with hypereosinophilic } \\
\text { syndrome }\end{array}$ & 1 & $\begin{array}{l}\text { Allogeneic cultured dermal } \\
\text { substitute using } \\
\text { cryopreserved normal } \\
\text { human fibroblasts on } \\
\text { matrix of hyaluronic acid } \\
\text { and Atelo-collagen; } \\
\text { replaced every } 3 \mathrm{~d} \text { for } 5 \mathrm{wk}\end{array}$ & $\begin{array}{l}\text { Pain reduction at site; } \\
\text { healthy granulation } \\
\text { tissue during } \\
\text { treatment and so } \\
\text { replaced with split } \\
\text { skin graft }\end{array}$ & Ohtani et al. 2004 \\
\hline & CDS & $\begin{array}{l}\text { Prospective } \\
\text { interventional } \\
\text { study }\end{array}$ & $\begin{array}{l}\text { Full thickness skin defects } \\
\text { following tumor } \\
\text { resection }\end{array}$ & 12 & $\begin{array}{l}\text { Allogeneic cultured dermal } \\
\text { substitute using } \\
\text { cryopreserved normal } \\
\text { human fibroblasts on } \\
\text { matrix of hyaluronic acid } \\
\text { and Atelo-collagen }\end{array}$ & $\begin{array}{l}\text { 9/10 patients developed } \\
\text { healthy granulation } \\
\text { tissue allowing split } \\
\text { skin graft; others } \\
\text { showed rapid } \\
\text { re-epithelialization }\end{array}$ & Moroi et al. 2004 \\
\hline
\end{tabular}




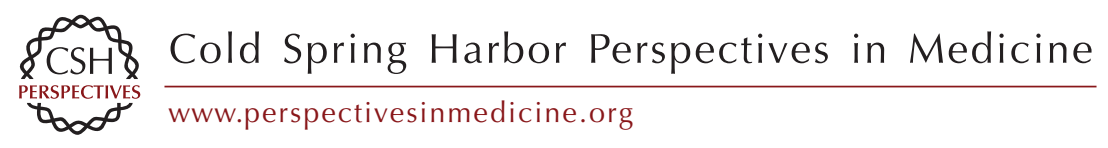

Table 1. Continued

\begin{tabular}{|c|c|c|c|c|c|c|}
\hline Cell type & Study type & Indication & Patient numbers & Components & Effect on wound healing & References \\
\hline CDS & Case report & Chronic venous ulcer & 1 & $\begin{array}{l}\text { Allogeneic cultured dermal } \\
\text { substitute using } \\
\text { cryopreserved normal } \\
\text { human fibroblasts on } \\
\text { matrix of hyaluronic acid } \\
\text { and Atelo-collagen }\end{array}$ & $\begin{array}{l}\text { Granulation tissue } \\
\text { within } 2 \mathrm{wk} \text {; } \\
\text { completely healed by } \\
9 \mathrm{wk}\end{array}$ & Hasegawa et al. 2007 \\
\hline CDS & $\begin{array}{l}\text { Multicenter } \\
\text { prospective } \\
\text { interventional } \\
\text { study }\end{array}$ & $\begin{array}{l}\text { Chronic venous and } \\
\text { arterial ulcer }\end{array}$ & 13 & $\begin{array}{l}\text { Allogeneic cultured dermal } \\
\text { substitute using } \\
\text { cryopreserved normal } \\
\text { human fibroblasts on } \\
\text { matrix of hyaluronic acid } \\
\text { and Atelo-collagen }\end{array}$ & $\begin{array}{l}\text { 9/13 cases (arterial }+ \\
\text { venous) healed well, } \\
\text { one complicated by } \\
\text { local infection; larger } \\
\text { ulcers still required } \\
\text { grafting }\end{array}$ & Yonezawa et al. 2007 \\
\hline CDS & Case report & $\begin{array}{l}\text { Ulcer associated with } \\
\text { antiphospholipid } \\
\text { syndrome }+ \text { stasis } \\
\text { dermatitis }\end{array}$ & 1 & $\begin{array}{l}\text { Allogeneic cultured dermal } \\
\text { substitute using } \\
\text { cryopreserved normal } \\
\text { human fibroblasts on } \\
\text { matrix of hyaluronic acid } \\
\text { and Atelo-collagen; } \\
\text { replaced every week }\end{array}$ & $\begin{array}{l}\text { All ulcers healed within } \\
4 \mathrm{wk}\end{array}$ & Nishimoto et al. 2007 \\
\hline CDS & $\begin{array}{l}\text { Prospective } \\
\text { interventional } \\
\text { study }\end{array}$ & $\begin{array}{l}\text { Intractable ulcers lower } \\
\text { leg }\end{array}$ & 5 & $\begin{array}{l}\text { Allogeneic cultured dermal } \\
\text { substitute using } \\
\text { cryopreserved normal } \\
\text { human fibroblasts on } \\
\text { matrix of hyaluronic acid } \\
\text { and Atelo-collagen }\end{array}$ & $\begin{array}{l}\text { Wound size decreased in } \\
\text { all cases ( } 33 \% \\
\text { reduction in seven } \\
\text { ulcers, complete } \\
\text { resurfacing in two } \\
\text { cases); no control } \\
\text { comparator }\end{array}$ & Yamada et al. 2008a \\
\hline CDS & $\begin{array}{l}\text { Prospective } \\
\text { interventional } \\
\text { study }\end{array}$ & $\begin{array}{l}\text { Wound donor site } \\
\text { following skin graft }\end{array}$ & 14 & $\begin{array}{l}\text { Comparative between fresh } \\
\text { and cryopreserved human } \\
\text { fibroblasts in allogeneic } \\
\text { cultured dermal substitute }\end{array}$ & $\begin{array}{l}\text { No difference noted in } \\
\text { re-epithelialization } \\
\text { between the } \\
\text { preparation methods }\end{array}$ & Yamada et al. 2008b \\
\hline CDS & $\begin{array}{l}\text { Prospective, open } \\
\text { label proof-of- } \\
\text { concept clinical } \\
\text { trial }\end{array}$ & Diabetic foot ulcer & 5 & $\begin{array}{l}\text { Autologous fibroblast seeded } \\
\text { artificial dermis using } \\
\text { animal product-free serum }\end{array}$ & $\begin{array}{l}3 / 5 \text { complete wound } \\
\text { healing within } 12 \mathrm{wk} \text {; } \\
\text { no deleterious effects } \\
\text { using animal-free } \\
\text { serum }\end{array}$ & Morimoto et al. 2012 \\
\hline
\end{tabular}




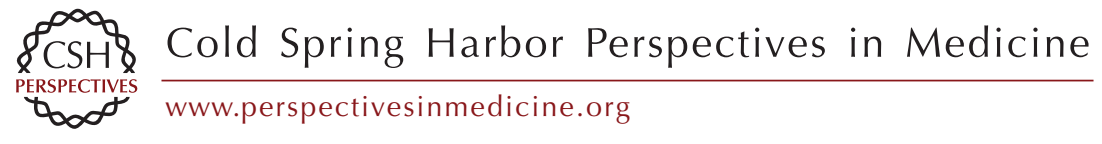

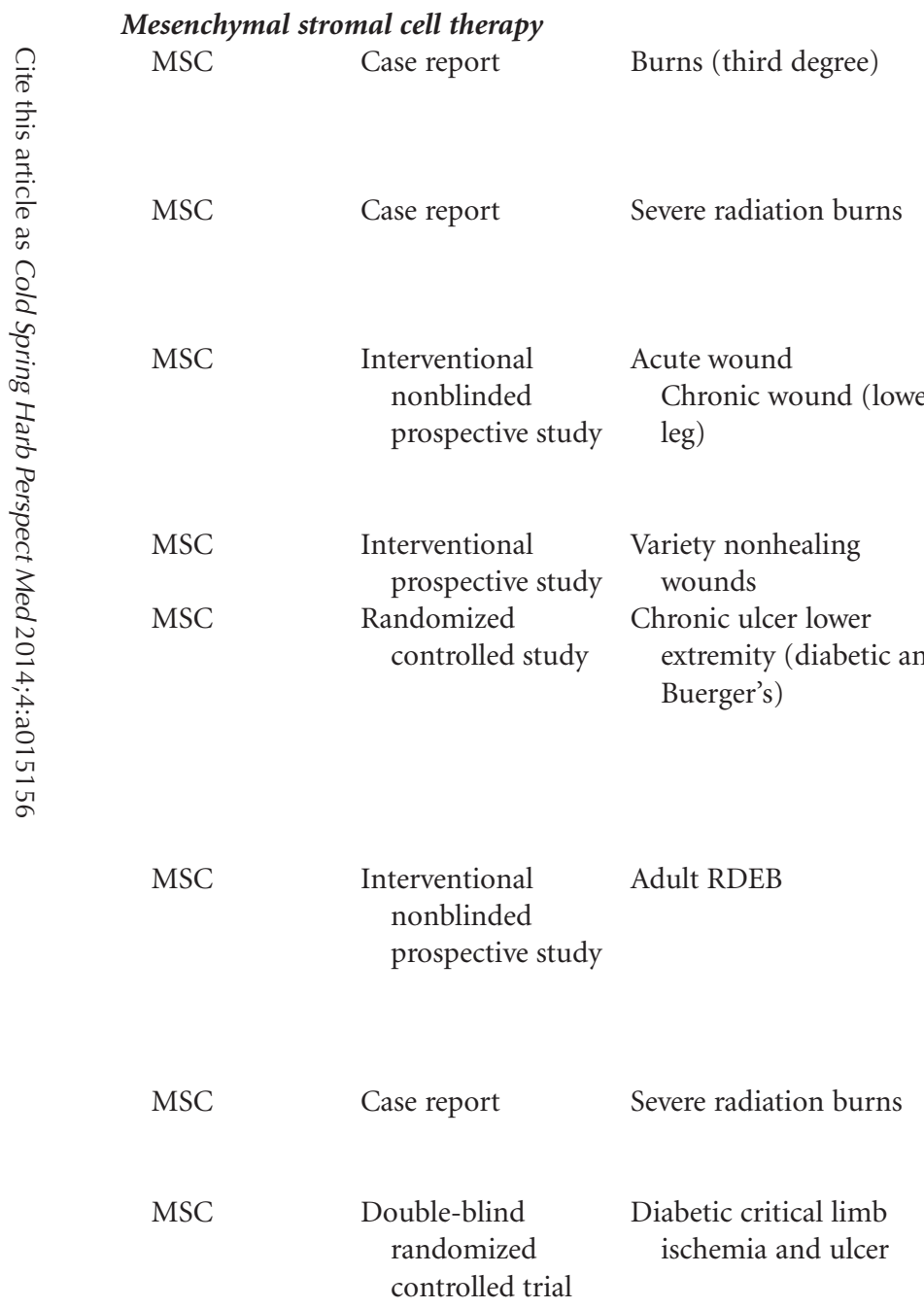

\begin{tabular}{|c|c|c|}
\hline $\begin{array}{l}\text { Allogeneic BM-MSC applied } \\
\text { directly to deep thermal } \\
\text { burn }\end{array}$ & $\begin{array}{l}\text { Wound regeneration } \\
\text { and accelerated } \\
\text { rehabilitation of } \\
\text { patient }\end{array}$ & Rasulov et al. 2005 \\
\hline $\begin{array}{l}\text { Intradermal cultured } \\
\text { autologous MSC }\end{array}$ & $\begin{array}{l}\text { No recurrence of } \\
\text { radiation } \\
\text { inflammatory waves } \\
\text { during } 11 \mathrm{mo} \mathrm{f} / \mathrm{u}\end{array}$ & Lataillade et al. 2007 \\
\hline $\begin{array}{l}\text { BM-derived cultured MSC } \\
\text { delivered in fibrin spray }\end{array}$ & $\begin{array}{l}\text { No control group but } \\
\text { detected correlation } \\
\text { between surface } \\
\text { density of MSC and } \\
\text { wound reduction }\end{array}$ & Falanga et al. 2007 \\
\hline $\begin{array}{l}\text { Cultured autologous BM- } \\
\text { derived MSC }\end{array}$ & $\begin{array}{l}\text { Wounds healed in } \\
18 / 20 \text { patients }\end{array}$ & Yoshikawa et al. 2008 \\
\hline $\begin{array}{l}\text { Cultured autologous BM- } \\
\text { derived MSC; single IM } \\
\text { injection + topical } \\
\text { application to wound }\end{array}$ & $\begin{array}{l}\text { Significant } \\
\text { improvement in } \\
\text { pain-free walking and } \\
\text { reduction in wound } \\
\text { size by } 72 \% \\
\text { compared with } \\
\text { control }\end{array}$ & Dash et al. 2009 \\
\hline $\begin{array}{l}\text { Intradermal allogeneic BM- } \\
\text { derived MSC }\end{array}$ & $\begin{array}{l}\text { Increased } \\
\text { epithelialization at } \\
\text { wound site; clinical } \\
\text { benefit for } 4 \mathrm{mo} ; \\
\text { de novo C7 } \\
\text { expression }\end{array}$ & Conget et al. 2010 \\
\hline $\begin{array}{l}\text { Intradermal cultured } \\
\text { autologous MSC }\end{array}$ & $\begin{array}{l}\text { No inflammatory } \\
\text { complications during } \\
8 \mathrm{mo} \mathrm{f} / \mathrm{u}\end{array}$ & Bey et al. 2010 \\
\hline $\begin{array}{l}\text { Autologous cultured BM- } \\
\text { MSC versus fresh } \\
\text { uncultured BM- } \\
\text { mononuclear cells versus } \\
\text { control (single IM }\end{array}$ & $\begin{array}{l}\text { Fastest healing time and } \\
\text { improvement in } \\
\text { pain-free walking } \\
\text { seen in MSC-treated } \\
\text { group }\end{array}$ & Lu et al. 2011 \\
\hline
\end{tabular}




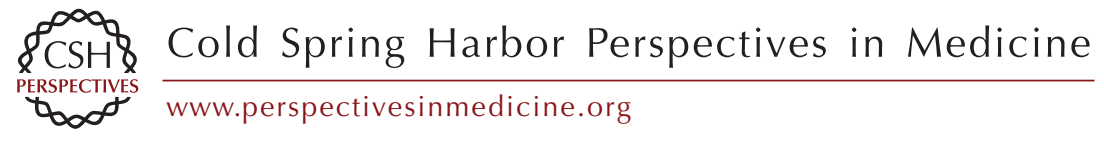

\begin{tabular}{|c|c|c|c|c|c|c|}
\hline Cell type & Study type & Indication & Patient numbers & Components & Effect on wound healing & References \\
\hline MSC & Case report & $\begin{array}{l}\text { Hypertrophic scar } \\
\text { following burn }\end{array}$ & 1 & $\begin{array}{l}\text { Intradermal BM-MSC + } \\
\text { split skin graft }\end{array}$ & $\begin{array}{l}\text { Reduction of skin graft } \\
\text { contracture } \\
\text { compared with } \\
\text { control site (graft } \\
\text { only) at } 2 \mathrm{yr} \mathrm{f} / \mathrm{u}\end{array}$ & Xu et al. 2012 \\
\hline MSC & $\begin{array}{l}\text { Prospective } \\
\text { interventional } \\
\text { study }\end{array}$ & Sclerodermatous GvHD & 4 & $\begin{array}{l}\text { Intra-BM injection of BM- } \\
\text { MSC derived from } \\
\text { unrelated donor; multiple } \\
\text { infusions }\end{array}$ & $\begin{array}{l}\text { Overall cutaneous } \\
\text { improvement } \\
\text { including healing of } \\
\text { ulcers, skin lesions, } \\
\text { less desquamation } \\
\text { and edema, with } \\
\text { greater joint mobility }\end{array}$ & Zhou et al. 2010 \\
\hline \multicolumn{7}{|c|}{ Adipose-derived stem cells } \\
\hline ADSC & $\begin{array}{l}\text { Multicenter phase } \\
\text { I/IIa clinical trial }\end{array}$ & $\begin{array}{l}\text { Complex perianal fistula- } \\
\text { Crohn's disease }\end{array}$ & 24 & $\begin{array}{l}\text { Cultured allogeneic adipose- } \\
\text { derived stem cells applied } \\
\text { intralesionally }\end{array}$ & $\begin{array}{l}56 \% \text { achieved closure of } \\
\text { fistula at week } 24 ; \text { no } \\
\text { adverse effects }\end{array}$ & $\begin{array}{l}\text { de la Portilla et al. } \\
2012\end{array}$ \\
\hline \multicolumn{7}{|c|}{ Bone marrow transplant } \\
\hline BM & $\begin{array}{l}\text { Prospective } \\
\text { interventional } \\
\text { study }\end{array}$ & Chronic wounds $>1 \mathrm{yr}$ & 3 & $\begin{array}{l}\text { Unfractionated BM, derived } \\
\text { cells directly applied to } \\
\text { wound }\end{array}$ & $\begin{array}{l}\text { Complete wound } \\
\text { closure in all patients; } \\
\text { dermal rebuilding } \\
\text { evident on histology }\end{array}$ & $\begin{array}{l}\text { Badiavas and Falanga } \\
\text { 2003a,b }\end{array}$ \\
\hline BMT & Interventional study & Pediatric Herlitz JEB & 1 & $\begin{array}{l}\text { Intravenous whole BMT } \\
\text { (matched related donor) } \\
\text { with conditioning and skin } \\
\text { graft from matched donor }\end{array}$ & $\begin{array}{l}80 \% \text { graft uptake; } \\
\text { patient death caused } \\
\text { by infection and } \\
\text { severe disease } \\
\text { phenotype }\end{array}$ & Kopp et al. 2005 \\
\hline BMT & Phase I clinical trial & Pediatric RDEB & 6 & $\begin{array}{l}\text { Intravenous whole BMT } \\
\text { (matched related donor) } \\
\text { with myeloablative } \\
\text { conditioning }\end{array}$ & $\begin{array}{l}\text { All show clinical } \\
\text { improvement; } 5 / 6 \\
\text { patients show } \\
\text { increased } \\
\text { levels C7 at DEJ }\end{array}$ & Wagner et al. 2010 \\
\hline
\end{tabular}




\section{$8_{\mathrm{CSH}}^{\infty} \mathrm{Cold}$ Spring Harbor Perspectives in Medicine \\ PERSPECTIVES www.perspectivesinmedicine.org}

$\mathrm{BM}$
Prospective
interventional
study
BMT + MSC Phase I
nonrandomized
interventional

study
BMT + MSC Phase I
nonrandomized
interventional
study

Chronic diabetic wounds

Pediatric RDEB

Pediatric JEB-Herlitz

$\operatorname{RDEB}(0.7-20 \mathrm{yr})$

BM-derived cells (TNC
fractionated BM) applied
to wound edge + platelets,
fibrin glue and BM
impregnated collagen
matrix
Intravenous whole BMT and
allogeneic MSC
Intravenous whole BMT and
adjuvant allogeneic MSC
therapy

Complete wound

closure in $3 / 8$

patients; reduction in

wound size in

remaining

\section{9 (7 underwent}

conditioning)

\section{3 (2 underwent conditioning)}
18 (13 myeloablative conditioning/5 nonmyeloablative conditioning) Nonmyeloablative
4/9 survived 12 mo posttransplant; all showed clinical improvement; increased levels of C7 in three patients $1 / 3$ patient survived

$12 \mathrm{mo}$

posttransplant; increased levels of

L332 in one patient conditioning well tolerated; BM preferred to UC transplant; 11 patients demonstrating partial to marked biochemical and clinical improvement in mucocutaneous disease on the basis of C7 expression, body surface area affected, and resistance to

blistering
Ravari et al. 2011

Tolar et al. 2012c

Tolar et al. 2013

TEN, toxic epidermal necrolysis; ADSC, adipose-derived stem cells; CDS, cultured dermal substitute; GvHD, graft versus host disease; HSCT, hematopoietic stem cell transplantation; MSC mesenchymal stromal cell; BM, bone marrow; RDEB, recessive dystrophic epidermolysis bullosa; C7, type VII collagen; BMT, bone marrow transplant; JEB, junctional epidermolysis bullosa; QOL, quality of life; RCT, randomized control trial; EBS, epidermolysis bullosa simplex; IM, intramuscular; TBSA, total body surface area; TNC, total nucleated cells; DEJ, dermal-epidermal junction; CEA, cultured epithelial autograft; f/u, follow-up. 
G. Petrof et al.

keratinocytes and dermal fibroblasts (Stanley et al. 1985; Regauer et al. 1990; Woodley et al. 2003; Goto et al. 2006; Ito et al. 2009). Given that fibroblasts are much easier to isolate and maintain in culture than keratinocytes, fibroblasts present an attractive target for cell-based therapies for RDEB. Normal and COL7A1-gene-corrected human RDEB fibroblasts overexpressing C7 have been injected intradermally into immunodeficient mouse skin or transplanted human RDEB skin equivalents (Ortiz-Urda et al. 2003; Woodley et al. 2003). Both these interventions led to sustained human C7 deposition and new anchoring fibril formation at the DEJ. It was also shown that intradermal injections of wild-type fibroblasts, that is, without COL7A1-gene correction, could correct the RDEB skin pathology, but only when injected at sufficient cell density (Woodley et al. 2003). Increase in C7 at the DEJ after intradermal injections of wild-type human fibroblasts was also confirmed in studies using a hypomorphic $\mathrm{C} 7$ mouse model of RDEB that expresses C7 at $\sim 10 \%$ of normal levels (Fritsch et al. 2008; Kern et al. 2009). Moreover, intravenously injected wild-type or COL7A1-gene-corrected human RDEB fibroblasts could home to wounded mouse skin and improve wound healing (Woodley et al. 2007). Collectively, these studies provide a rationale for the use of allogeneic wild-type or COL7A1-gene corrected fibroblasts in human RDEB studies.

\section{FIRST-IN-MAN USE OF FIBROBLASTS IN DYSTROPHIC EB}

Based on the mouse data, a proof-of-concept study in five RDEB subjects showed that a single intradermal injection of allogeneic fibroblasts $\left(5 \times 10^{6}\right.$ cells in $25-\mu l$ volume injected into the superficial dermis over an $\sim 1 \mathrm{~cm}^{2}$ area) increased COL7A1 gene expression for at least 3 mo (the end point of that study) in most individuals (Wong et al. 2008). The study also showed the low immunogenicity of allogeneic fibroblasts and lack of host response at an immunological and histological level. The injected cells were not detectable at $2 \mathrm{wk}$ postinjection, the time point at which an increase in $\mathrm{C} 7$ protein at the DEJ was seen. Of note, the increase in C7 was most apparent in RDEB subjects who had some baseline expression of C7 compared to those who had a complete absence of the protein. However, the increase in C7 was not accompanied by the formation of new, normal-appearing anchoring fibrils; there was an increase in the number of fibrillar structures below the lamina densa of the basement membrane, but these were somewhat wispy and lacked characteristic ultrastructural features of mature anchoring fibrils. Nevertheless, there was some subjective evidence for increased epidermal-dermal adhesion following the allogeneic fibroblast injections. Given the increase in COL7A1 gene and C7 protein expression beyond the physical presence of the injected allogeneic cells, however, the changes were thought to be caused by a paracrine effect induced by the fibroblasts. A subsequent study was able to show that a single injection of allogeneic fibroblasts could increase COL7A1 gene expression for 3-6 mo and C7 protein for 9-12 mo (Nagy et al. 2011).

\section{MODE OF ACTION OF ALLOGENEIC FIBROBLAST CELL THERAPY IN DYSTROPHIC EB}

Transcriptomic analysis of serial skin biopsies following injection of allogeneic fibroblasts in one subject with RDEB revealed that expression of heparin-binding epidermal growth factorlike growth factor $(H B-E G F)$ was up-regulated and that expression levels mirrored those seen for the COL7A1 gene (Nagy et al. 2011). In vitro studies were able to show that HB-EGF could up-regulate COL7A1 gene expression in both normal-control and RDEB keratinocytes and fibroblasts, and this was preceded by increased expression of JUN and FOS, components of the AP1 transcription factor that are known to bind to and up-regulate COL7A1. The interpretation of the in vivo situation was that allogeneic fibroblasts were able to induce up-regulation of HB-EGF, predominantly in neighboring keratinocytes. The HB-EGF could then lead to a sustained increase in $\mathrm{C} 7$ by acting in an autocrine, paracrine, and juxtacrine manner to up-regulate COL7A1. The new C7 was thought to be predominantly recipient-derived, that is, mutant 
but partially functional. A slight increase in $H B$ EGF and COL7A1 gene expression was also noted after injection of saline into skin, although up-regulation was less marked than following fibroblast injection and was for a shorter duration. It is also plausible that the donor fibroblasts could release wild-type full length C7 for incorporation into the $\mathrm{DEJ}$ during the time (few days) the cells are present in the RDEB skin. Evidence for this "direct release" theory is supported by studies in mice (Kern et al. 2009), although both mechanisms are not mutually exclusive. Although often thought as differentiated somatic cells, cultured skin fibroblasts may also contain a subpopulation of cells with stem cell properties, capable of differentiation into mesoderm, endoderm, and ectoderm. Termed MUSE (multilineage-differentiating stress-enduring) cells, these cells are also found in the skin and BM (Wakao et al. 2011).

\section{FIBROBLAST CELL THERAPY AND WOUND HEALING IN DYSTROPHIC EB}

The initial studies of allogeneic fibroblast injections in RDEB focused on responses at the DEJ in intact skin. However, the major clinical burden in affected individuals is poor wound healing. One randomized double-blind study that assessed the impact of allogeneic fibroblasts in wound healing in RDEB showed no differences in the extent or rate of re-epithelialization of chronic erosions following injection of fibroblasts or inert carrier solution (Venugopal et al. 2013). In contrast, another clinical trial found that a single injection of allogeneic fibrobalsts can speed up wound healing for $28 \mathrm{~d}$ compared to vehicle (Petrof et al. 2013). The putative upregulation of HB-EGF following allogeneic fibroblast injection (Nagy et al. 2011) may have benefits for wound healing beyond up-regulation of C7, given that HB-EGF has been shown to promote keratinocyte migration (Shirakata et al. 2005). However, one caveat may be the effects of HB-EGF on epidermal growth factor receptor signaling and risk of malignancy (Zenz et al. 2003). Given that individuals with RDEB have an increased incidence of squamous cell carcinoma, especially in chronic wounds (Fine and Mellerio 2009a), further safety monitoring of allogeneic fibroblasts injected into RDEB wounds is required. At the bedside, allogeneic fibroblasts have been used off licence to treat a number of patients with RDEB (Fig. 1). The clinical impression and experience indicates that for a subgroup of individuals with RDEB, notably those with mild to moderate disease severity and some baseline expression of $\mathrm{C} 7$ at the DEJ, allogeneic fibroblast therapy may be useful, in contrast to those individuals with more severe disease that lack C7 expression. For the latter individuals, alternative cell therapy or other strategic approaches may be more effective.

\section{BM STEM CELLS AND THE SKIN}

BM stem cells have a fundamental role in generating erythrocytes, leukocytes, and platelets, but also show plasticity in being able to show lineage differentiation into tissues of mesodermal, endodermal, and ectodermal origin, including skin (Grove et al. 2004). Some subpopulations of BM cells can differentiate into keratinocytes (Badiavas et al. 2003a; Borue et al. 2004; Fathke et al. 2004), and in humans who have undergone bone marrow transplanta-

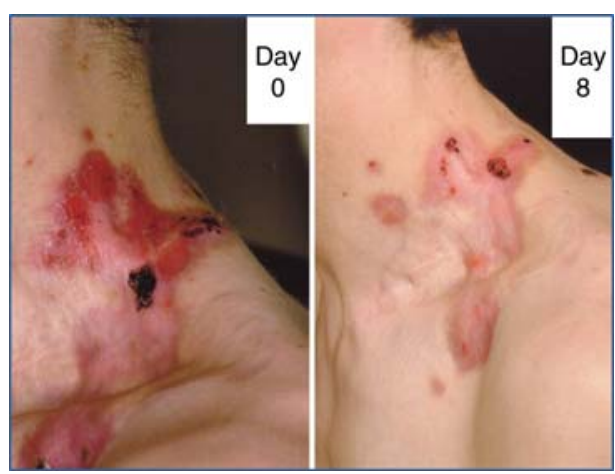

Figure 1. Intradermal injections of allogeneic fibroblasts promote wound healing in RDEB. A stubborn wound on the side of the neck in this 23-yr-old man with RDEB showed limited improvement and persisting erosions after skin grafting. However, $8 \mathrm{~d}$ after fibroblast injection there was significant healing of erosions and improved quality of life; he was able to wear a shirt without discomfort. The clinical benefits of the fibroblast injections lasted for 5-6 mo. 
G. Petrof et al.

tion (BMT), donor cells that have differentiated into keratinocytes can be detected in the epidermis for at least $3 \mathrm{yr}$ (Korbling et al. 2002). Further studies have shown that the BM is also a source of fibroblast-like cells in the dermis (of hematopoietic and mesenchymal lineages) and that the number of these cells increases after skin wounding (Fathke et al. 2004; Ishii et al. 2005; Sasaki et al. 2008). BM cells also contribute to skin development; infusion of BM cells in utero in mice leads to accumulation of a subpopulation of these cells in the dermis, particularly around developing hair follicles (Chino et al. 2008). Overall, however, BM-derived keratinocytes appear to be an extremely rare finding, perhaps contributing only $\sim 0.0001 \%-$ $0.0003 \%$ of all cells in the new epidermis (Tamai et al. 2011). The physiological role of BM cells in epithelial regeneration therefore has been questioned, although recent studies focusing on RDEB have started to provide new insight into key BM cells and mechanisms germane to skin repair and regeneration.

\section{MURINE STUDIES OF BM CELLS AND SKIN REPAIR}

Initial attempts to use BM cells to correct the inherent skin fragility of RDEB were made in the Col7al knockout mouse that recapitulates some of the features of the human disease (Heinonen et al. 1999; Tolar et al. 2009). Nonmanipulated $\mathrm{BM}$ failed to rescue the RDEB mice, but alternative use of the signaling lymphocyte activating molecule (SLAM)-positive subpopulation of BM cells resulted in new C7 and presence of donor cells at the DEJ. Following infusion of SLAM-positive BM cells, there was improved healing of blisters on the mouth and paws, and histological evidence of rudimentary anchoring fibril formation (Tolar et al. 2009). Other studies have also shown correction of RDEB skin defects with BM cells (Fig. 2), that repair can occur after in utero infusion of BM cells (Chino et al. 2008), and BM-derived mesenchymal stromal cells (MSCs) can stimulate secretion of C7 with partial restoration of the damaged basement membrane zone and less blister formation (Alexeev et al. 2011). In a different mouse that

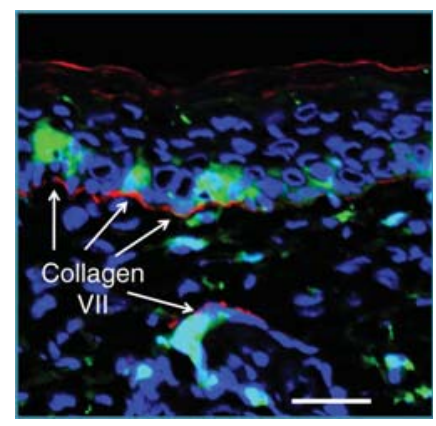

Figure 2. BM cells can correct lack of $\mathrm{C} 7$ in $\mathrm{RDEB}$ mouse skin. Grafting of mouse skin lacking C7 onto a mouse with green fluorescent BM leads to some BM cells entering the epidermis and follicular epithelium. Moreover, new basement membrane C7 (red) is noted in proximity to these green cells. Scale bar, $25 \mu \mathrm{m}$. (This figure is based on data reported by Tamai et al. 2011.)

lacks type XVII collagen, a model for non-Herlitz junctional EB, both hematopoietic and nonhematopoietic BM stem cells have been shown to correct basement membrane protein expression and lead to phenotypic rescue (Fujita et al. 2010). Collectively, these murine studies provide a scientific rationale for translation of $\mathrm{BM}$ cell therapies into human clinical trials. Moreover, several additional mouse models for different forms of EB have been developed recently that will also be useful for assessing BM cell therapy, including the hypomorphic $\mathrm{C} 7$ mouse (Fritsch et al. 2008) and a hypomorphic model for non-Herlitz junctional EB with a spontaneous mutation in the Lamc2 gene (Bubier et al. 2010).

\section{FIRST-IN-MAN STUDIES OF MSC THERAPY IN DYSTROPHIC EB}

The use of intradermal MSC therapy was first reported in two patients with RDEB in 2010 (Conget et al. 2010), although successful topical use of BM cells to heal chronic wounds in other diseases has been reported previously (Badiavas and Falanga 2003b; Humpert et al. 2005; Falanga et al. 2007). The MSCs used in the RDEB study were derived from the BM of a healthy, unrelated individual. The RDEB subjects had a complete 
absence of C7 expression at the DEJ on immunofluorescence microscopy and clinically had severe blistering and wounds that healed slowly with scarring. The investigators injected $0.5 \times$ $10^{6}$ MSCs or vehicle into both intact and chronically ulcerated sites (Fig. 3). Skin biopsy was performed $1 \mathrm{wk}$ after intervention and showed that the MSC-treated skin expressed C7 at the DEJ. Moreover, there was re-epithelialization of chronically ulcerated skin near the MSC injection site, but not near the vehicle injected site. Both patients in the study showed clinical benefits that lasted for 4 mo. Thereafter, the skin fragility resembled the pretreatment state. No adverse effects were noted in the injected skin or systemically. This pilot study showed that the intradermal administration of allogeneic MSCs can lead to de novo C7 expression at the DEJ as well as preventing blistering and improving

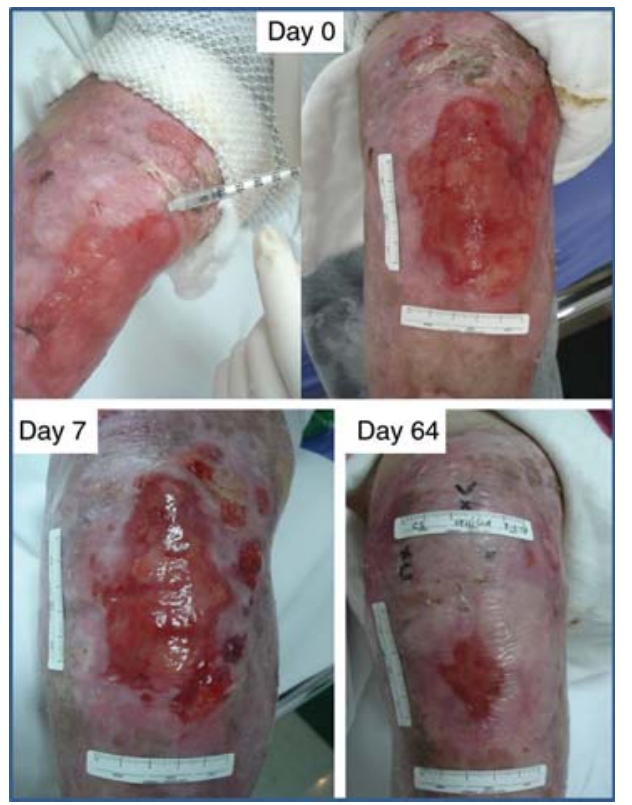

Figure 3. Healing of a chronic erosion in RDEB is enhanced by intradermal injection of allogeneic MSCs. Injecting third-party BM-derived MSCs, as shown in the day 0 image (top left), leads to re-epithelialization and clinical improvement seen at day 7 and day 64. The clinical benefits were sustained for 4-6 mo. (The original images were kindly provided by Dr. Francis Palisson, based on data reported by Conget et al. 2010.) wound healing in patients with RDEB. A clinical trial using intravenous unrelated donor BMderived MSCs in subjects with RDEB has recently been performed (M El Darouti, pers. comm., 2012). Although no skin biopsies were performed in that study, clinical evaluation reported a reduction in the number of blisters, less skin inflammation, better wound healing, and improved quality of life, which lasted for 46 mo following a single infusion of MSCs. Further evaluation of systemic MSCs in RDEB is anticipated.

\section{BMT IN DYSTROPHIC EB}

Following the effectiveness of BM stem cells in murine RDEB, a clinical trial of whole BMT was performed in children with RDEB (Wagner et al. 2010). The approach used high-dose chemotherapy to immunoablate individuals with RDEB to permit more reliable lymphohematopoietic engraftment. The BM was not filtered so that all the hematogenous populations could be preserved, allowing for the possibility that nonhematopoietic MSC populations might also be needed for clinical benefits. Seven patients entered the trial and six underwent BMT. All individuals had some clinical improvement and five of the six showed increased C7 at the DEJ (Fig. 4). The first patient in the trial is now $5 \mathrm{yr}$ since transplantation. Before the BMT, each individual had more than $50 \%$ of their skin covered with blisters and erosions. Three of the six individuals showed a dramatic clinical improvement, such that $<10 \%$ of the body surface area remained affected. In the other three subjects, there was a moderate improvement with less than $25 \%$ of the body surface area affected. Despite the clinical improvement, some toxicity was noted. One patient died before the BMT because of heart failure, possibly related to cyclophosphamide toxicity and pre-existing renal failure. Another individual died 6 mo after transplantation because of infection secondary to graft failure. Translational research is now attempting to refine BMT protocols to consider use of reduced intensity conditioning and perhaps subpopulations of BM cells once mechanisms of action in repairing defective EB skin 
G. Petrof et al.

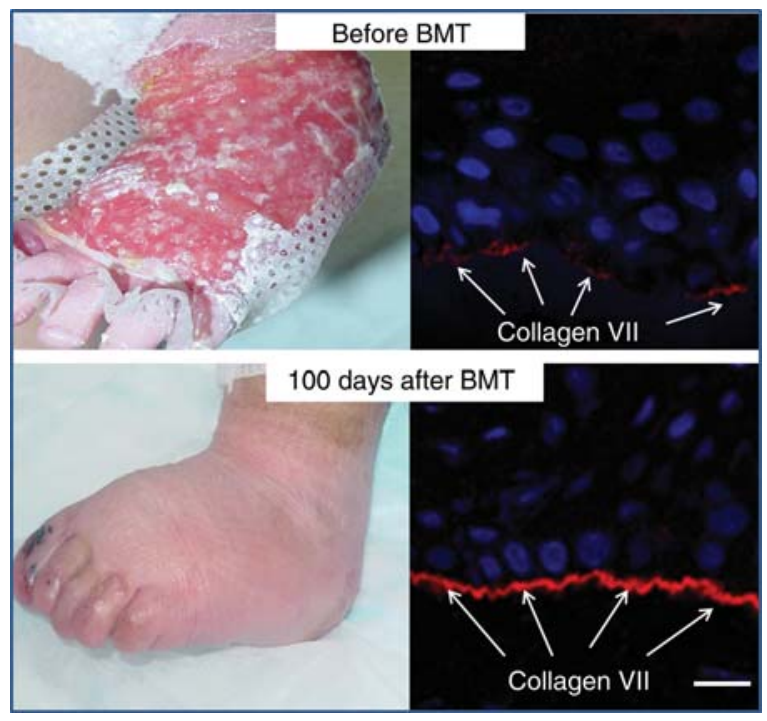

Figure 4. Whole BMT results in clinicopathological correction of the skin pathology in RDEB. This 15-mo-old child shows a marked improvement with healing of chronic wounds and fewer blisters $100 \mathrm{~d}$ after BMT. There is also increased C7 at the DEJ (arrows). Scale bar, $25 \mu \mathrm{m}$. (The original images were kindly provided by Dr. Jakub Tolar, based on data reported by Wagner et al. 2010.)

are better known. Clinical application of BMT is also being expanded to Herlitz and non-Herlitz junctional EB, although RDEB remains the predominant clinical indication for now.

\section{MODE OF ACTION OF SKIN REPAIR IN DYSTROPHIC EB FOLLOWING BMT}

The precise mode of action of BMT leading to clinicopathological improvement in RDEB is not known. High levels of chimerism (donor and recipient cells) were noted in skin after BMT, with donor nonhematopoietic cells being the probable source of new $\mathrm{C} 7$ at the DEJ. Notably, although there were some hematopoietic cells in the skin $\left(\mathrm{CD} 45^{+}\right)$, the majority were nonhematopoietic, nonendothelial cells $\left(\mathrm{CD} 45^{-}, \mathrm{CD} 31^{-}\right)$. In spite of the increased $\mathrm{C} 7$, however, there was a lack of normal anchoring fibrils on transmission electron microscopy. Although the lack of these adhesion structures may relate to gradual maturation of new anchoring fibrils (as has been observed for several months following burns), it is plausible that some of the increased C7 may reflect an up-regulation of mutant but partially functional en- dogenous $\mathrm{C} 7$, similar to the proposed mode of action for allogeneic fibroblast therapy. Clearly, however, there is more to the reparative story in that the transplanted RDEB patient who did not show any increase in C7 also showed a sustained clinical response in skin healing and integrity at the DEJ. This may indicate the incorporation or availability of additional extracellular matrix proteins that can contribute to better skin repair and adhesion, although such a possibility remains speculative. Functional improvement in skin adhesion in patients following BMT was shown by progressive increases in suction blister times (the time it takes to form a blister following placing a negative-pressure suction cup on the skin surface). Although mode of action of BMT in skin repair in EB continues to be investigated, current clinical data provide evidence for a sustained functional improvement in the majority of patients.

\section{EPITHELIAL PROGENITORS WITHIN SUBPOPULATIONS OF BM STEM CELLS}

A recent study has shown that BM contains a specific population of epithelial progenitors and 
that these are mobilized and recruited by certain key factors. Tamai et al. (2011) used an irradiated mouse model in which green fluorescent protein-labeled BMT was performed. Subsequent skin grafting in this mouse was able to identify that BM-derived keratinocytes are not of hematopoietic origin, but instead are derived from a specific subpopulation of lineage-negative, platelet-derived growth factor receptor $\alpha$ positive $\left(\mathrm{Lin}^{-} / \mathrm{PDGFR} \alpha^{+}\right) \mathrm{BM}$ cells. This is still a somewhat heterogeneous cell population that represents approximately 1 in $450 \mathrm{BM}$ cells. Indeed, these cells may show lineage overlap with other defined subpopulations of MSCs, including multipotent adult progenitor cells, $\mathrm{Lin}^{-} /$ $\mathrm{SCAR}^{+} / \mathrm{CD} 45^{-}$very small embryonic-like stem cells in $\mathrm{BM}, \mathrm{CD} 45^{-}$unrestricted somatic cell stems in cord blood, and nestin-positive cells that maintain the stem cell niche with hematopoietic stem cells in BM. The study by Tamai et al. (2011) proposed that the skin graft acted as a hypoxic bioreactor, rapidly releasing the nonhistone nuclear protein high-mobility group box-1 (HMGB1). Following skin grafting, HMGB1 levels in serum increased and HMGB1 was shown to mobilize these cells along an HMGB1 concentration gradient to the area of hypoxic keratinocytes. Differentiation of these cells into keratinocytes was clearly shown. The study also showed that in RDEB the main source of HMGB1 was hypoxic keratinocytes in blister roofs. The implication of this study is that there is a subpopulation of nonhematopoietic $\mathrm{BM}$ cells comprising $\sim 0.22 \%$ of the BM population that has the capacity to restore defective epithelium, including targeting and correcting the pathology of RDEB.

\section{BMT FOR OTHER INHERITED SKIN DISEASES}

BMT has been used as a form of stem cell therapy for more than 40 years and is really the only stem cell therapy with a definite therapeutic benefit. Although the initial applications were for leukemia, lymphoma, aplastic anemia, and hemoglobinopathies, the clinical indications for BMT have expanded and approximately 50,000 people worldwide have received this form of therapy. As well as clinical trials in
RDEB, BMT is being investigated in other forms of EB including Herlitz junctional EB (Tolar et al. 2012b). One further consideration in Herlitz junctional EB, however, is that the defective protein (laminin-332) is not synthesized by fibroblasts (unlike C7); it is only generated by keratinocytes. Thus, whether corrective donor cells in the dermis can secrete the defective basement membrane protein is uncertain. Perhaps correction of epithelial cells is essential in this form of EB. Nevertheless, early studies have indicated that BMT may increase laminin-332 expression at the DEJ in some individuals. It is still too early, however, to reflect on the clinical indications and possible benefits from this treatment. The same caveats exist for epithelial synthesized proteins germane to non-Herlitz junctional EB in which either laminin-332 or type XVII collagen may be defective, although the clinicopathological improvement seen in type XVII collagen-deficient mice after BM cell therapy provides some justification for human studies (Fujita et al. 2010). Gradually, therefore, it seems likely that other forms of EB associated with severe morbidity may be evaluated in clinical trials of BMT. Conceptually, this form of cell therapy should still be regarded as a highly experimental procedure.

\section{UMBILICAL CORD BLOOD TRANSPLANTATION AND THE SKIN}

Cord blood (CB) and other parts of the umbilical cord, such as the Wharton's jelly or tissues associated with the placenta, are rich sources of stem cells. Like hematopoietic stem cells, CB is an important source of other progenitor cells, as well as MSCs, very small embryonic-/epiblast-like stem cells and unrestricted somatic stem cells, which may have individual or collective value in regenerative medicine. Using some stem cell populations, notably the MSCs, a number of clinical studies have been initiated, mostly to repair tissue, including some studies on skin. The first transplant in humans using $\mathrm{CB}$ was reported in 1989 with the use of human leukocyte antigen-matched sibling $\mathrm{CB}$ to treat Fanconi anemia (Gluckman et al. 1989). Subsequently, CB banks were established for the 
G. Petrof et al.

collection and cryopreservation of cells and more than 20,000 CB transplants have been performed worldwide. MSCs from CB are similar to BM-derived MSCs in having low immunogenicity and are already being used in several studies of regenerative medicine. That said, comparison of umbilical cord cells versus BM stem cells in individuals with RDEB has shown better skin engraftment with a BM-derived population (Tolar et al. 2012a) and, therefore, the clinical utility of cord cells in EB or other skin disorders remains to be determined in future clinical trials. Recent, preclinical data, however, have shown that unrestricted somatic stem cells can express C7 and accelerate wound healing, including improving the quality of wound healing, as evidenced by formation of new skin appendages (Liao et al. 2013).

\section{REVERTANT MOSAICISM AND SPONTANEOUS NATURAL CELL THERAPY}

One striking observation in recent years has been that some patches of skin in patients with various inherited skin diseases can under- go spontaneous correction of the genetic defect underlying the skin pathology, a concept known as revertant mosaicism or "natural gene therapy." This was first noticed in the late 1990s in a patient with non-Herlitz junctional EB resulting from autosomal recessive mutations in type XVII collagen (Jonkman et al. 1997). Revertant mosaicism is a naturally occurring process characterized by spontaneous genetic repair that can lead to a partial or complete reversal of an affected to a wild-type phenotype (Fig. 5). In addition to non-Herlitz junctional EB, other variants of EB including EB simplex, RDEB, and Kindler syndrome have all shown evidence of revertant mosaicism (Lai-Cheong et al. 2011). Likewise, skin diseases such as ichthyosis with confetti and dyskeratosis congenita have also been shown to display this phenomenon. Indeed, a recent study has suggested that in vivo reversion may occur in all patients with generalized non-Herlitz junctional EB (Pasmooij et al. 2012). The predominant mechanisms of gene correction include back mutation, gene conversion, intragenic recombination, and second-site mutation. The genetic correction appears to

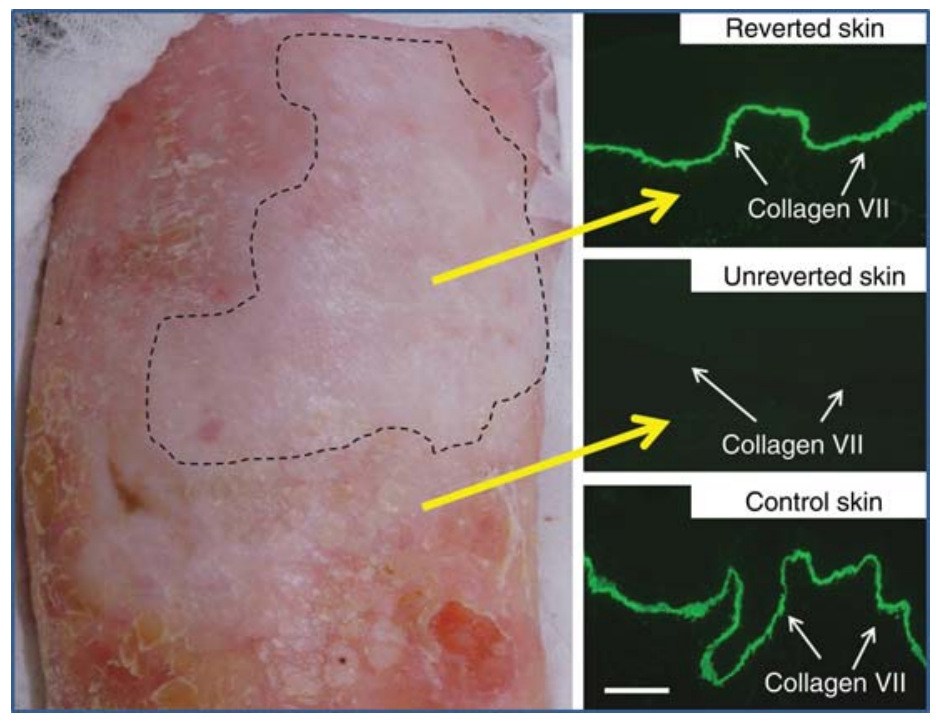

Figure 5. Revertant mosaicism represents a form of natural gene therapy in RDEB skin. This 40-yr-old man with RDEB has a patch of skin on his right shin that does not blister (unlike the surrounding skin that blisters after minor trauma). Skin from the reverted area shows near-normal intensity C7 immunoreactivity at the DEJ in contrast to the complete absence of C7 in the unreverted skin. Scale bar, $25 \mu \mathrm{m}$. (Images are based on data reported by Almaani et al. 2010.) 
be limited to keratinocytes rather than fibroblasts or other cell populations, perhaps reflecting higher proliferation rates in keratinocytes (Jonkman et al. 1997). The main clinical consequence of revertant mosaicism is the phenotypic improvement of disease, although the timing of the reversion may influence the extent of revert mosaicism and the severity of the condition, that is, early reversion of events during embryonic development is more likely to result in larger revertant patches.

\section{REVERTANT CELL THERAPY FOR EB}

The opportunity to expand keratinocytes derived from a patch of revertant mosaicism creates a translational opportunity for revertant cell therapy that is personalized and patient specific. The key advantage of this approach is that the cells are naturally corrected and, therefore, additional genetic manipulation should not be necessary. The first attempt at revertant cell therapy was reported in an individual with revertant mosaicism in non-Herlitz junctional EB (Gostynski et al. 2009). Revertant keratinocytes from this patient were isolated, expanded into epidermal sheets, and grafted onto a de-epidermized area of mutant skin. In culture, $\sim 30 \%$ of keratinocytes displayed reversion, but, for reasons unknown, fewer than $3 \%$ of the corrected cells persisted in the graft and thus clinically, the graft remained fragile and skin integrity did not improve. This case provided proof-of-principle about the feasibility of revertant cell therapy, but showed that further optimization would be required for successful transplantation. Future improvements in graft production and maintenance of reversion in culture might lead to better function in future attempts at skin transplantation. An alternative approach might be to use pinch/punch grafting using skin from the revertant patches and transplanting these pieces of "normal" skin into affected areas within the same individual. For example, this may be clinically useful if reverted skin was seeded adjacent or within chronic erosions to promote wound healing. Whether creating minor injury to the edge of a patch of revertant mosaicism would lead to expansion of area of reverted ke- ratinocytes is not known; most patches of reversion tend to enlarge initially, but then remain static (Lai-Cheong and McGrath 2013). Although fibroblast culture is considerably easier than keratinocyte culture (especially in patients with EB), the lack of demonstrable revertant mosaicism in fibroblasts means that revertant cell therapy is not possible with this cell population.

\section{FUTURE CELL THERAPY STRATEGIES: I. REFINEMENT OF EXISTING BM CELL PROTOCOLS}

Although the majority of RDEB children who participated in the initial BMT trial showed remarkable clinical benefit, two of seven children died (one before BMT) (Wagner et al. 2010). To try to reduce morbidity and mortality, additional protocols have been developed to use reduced intensity conditioning rather than full myeloablation. Modifications to the original protocol, such as the additional subsequent infusion of MSCs from the original donor, have also been adopted. A further issue is whether to use a subpopulation of cells that can specifically repair skin and mucous membranes. For example, use of the $\mathrm{Lin}^{-} / \mathrm{PDGFR} \alpha^{+}$MSCs that were previously shown to harbor epithelial progenitors might be suitable (Tamai et al. 2011). Another consideration may be just to use allogeneic MSCs, as has been trialed in several other diseases because of their anti-inflammatory properties. MSCs can home to damaged tissue and release various immunomodulatory factors that influence the behavior of dendritic cells, T cells, and natural killer cells. MSCs can reduce Bcell proliferation, monocyte maturation, secretion of IFN- $\gamma$ and TNF- $\alpha$ while promoting induction of T-regulatory cells and secretion of anti-inflammatory IL-10 from macrophages in direct contact with MSCs. Although the precise microenvironmental contributions to tissue repair are not fully known, a more detailed understanding of the trophic mechanisms associated with MSCs in tissue regeneration is likely to lead to further exploration of clinical utility. In general, whatever immune conditioning or cell population is being planned for use as cell 
G. Petrof et al.

therapy, for diseases such as EB, it is evident that treatment that is both systemic and given at an early age is likely to have the most clinical benefit, certainly for patients with widespread disease.

\section{FUTURE CELL THERAPY STRATEGIES: II. TARGETING OF SUBPOPULATIONS OF BM CELLS TO DAMAGED SKIN}

The murine wound healing studies performed by Tamai et al. (2011) provide some insight into how skin grafting may work. Grafting a split thickness or full thickness piece of skin to ulcers and burns is widely used in clinical practice and the benefits may be derived from direct restoration of a covering skin barrier. A further reparative mechanism, however, might be through local release of HMGB1 into the circulation with recruitment of $\mathrm{Lin}^{-} / \mathrm{PDGFR} \alpha^{+}$cells from the BM. Large skin grafts might release sufficient HMGB1 into the sera to reach a threshold that is sufficient to mobilize this subpopulation of MSCs from BM. Smaller skin grafts that do not release sufficient HMGB1 to reach threshold would not be expected to have the capacity to mobilize these cells unless additional local or systemic HMGB1 was given. The recruitment of $\mathrm{Lin}^{-} / \mathrm{PDGFR} \alpha^{+}$cells to a skin graft may be dependent on the gradient of HMGB1 (i.e., the local skin levels initially being greater than those in the serum). Although patients with RDEB have been shown to have increased HMGB1 in their blister fluid (released from the damaged keratinocytes in the blister roof) and serum (Tamai et al. 2011), it is not known whether this elevated HMGB1 can mobilize the $\mathrm{Lin}^{-} /$ PDGFR $\alpha^{+}$cells from the patient's BM, or whether there may be some partial or complete exhaustion of these cells because of the chronic subepidermal skin blistering. BMT strategies aimed at restoring this cell population or promoting targeting of these particular MSCs in patients with RDEB may be helpful in tissue repair, including mobilization of these MSCs from $\mathrm{BM}$ or recruitment to damaged skin being augmented by use of recombinant HMGB1. These MSCs may also represent an additional attractive target for COL7A1 gene therapy.

\section{FUTURE CELL THERAPY STRATEGIES: III. COMPLEMENTARY APPROACHES WITH COMBINATION GENE THERAPY}

Although phase I/II clinical trials of cell therapy in EB have been initiated, it is clear that the ideal therapy for EB is unlikely to involve just allogeneic cells. More likely to be clinically useful is a combination of gene, protein, drug, and cell therapies. To that end, some progress is being made, although so far, only one proof-of-principle study has been published using somatic gene therapy in EB (Mavilio et al. 2006). In that study, a retroviral vector was used to insert the LAMB3 transgene into autologous keratinocytes that were then grafted back as a confluent sheet onto the thigh of an adult male with nonHerlitz junctional EB. One key practical problem was the lack of holoclone stem cells in the patient, which was probably a consequence of long-term skin blistering. Over the subsequent $6 \mathrm{yr}$, however, the graft has continued to express laminin-332 at the DEJ with functional improvement and lack of blistering. Other studies of gene therapy, notably for RDEB, are at preclinical or early clinical stages mostly involving ex vivo keratinocyte grafting following introduction of a transgene or correction of both keratinocytes and fibroblasts and construction of a skin equivalent. Whether keratinocytes are the ideal cell to target, however, is debatable. Local gene therapy might involve genetic correction of autologous fibroblasts with the reparative transgene, an approach that might avoid the probable pitfalls of wound infection and graft loss using a topical approach in RDEB. Alternatively, if systemic gene therapy is used, it may be more appropriate to target BM cells that include epithelial progenitors or cells that can contribute to skin repair.

\section{FUTURE CELL THERAPY STRATEGIES: IV. COMPLEMENTARY APPROACHES WITH COMBINATION PROTEIN AND DRUG THERAPIES}

With regard to protein therapy, this has also been tested with recombinant C7 in small and large animal models of RDEB (Palazzi et al. 2000; 
Woodley et al. 2013). Initial studies used C7-null mice showed that intradermally injected recombinant C7 resulted in linear organization of C7 at the DEJ and formation of anchoring fibrils (Remington et al. 2009). Subsequent intravenous infusion of recombinant C7 was shown to home to wounds in murine RDEB models and restore $\mathrm{C} 7$ expression and function. Subsequently, a naturally occurring RDEB dog model has been used to test intravenous protein therapy (Palazzi et al. 2000). Although not yet at a clinical stage, it is likely that intradermal, and possibly intravenous, delivery of $\mathrm{C} 7$ will transfer into clinical trials shortly. It is also likely that some individuals with EB will benefit from a new group of compounds that have the capability of inducing readthrough of nonsense mutations (Arakawa et al. 2003; Cardno et al. 2009). Several recessive forms of EB involve loss-offunction mutations. Notably, in RDEB, $\sim 15 \%$ of all pathogenic mutations involve nonsense mutations (Dang and Murrell 2008) and these are likely to be a focus for readthrough therapeutics. Such drugs can increase mRNA expression by $\sim 5 \%-10 \%$, leading to increased protein synthesis (Rowe and Clancy 2009). Given that mouse models of RDEB have indicated that it is necessary to have $30 \%-40 \%$ of normal levels of $\mathrm{C} 7$ at the DEJ to prevent blistering (Fritsch et al. 2008; Kern et al. 2009), the use of a systemic readthrough drug in appropriate patients may help contribute toward this target and complement other therapies.

\section{FUTURE CELL THERAPY STRATEGIES: V. COMBINING REVERTANT MOSAICISM WITH INDUCIBLE PLURIPOTENT STEM CELL TECHNOLOGIES}

One potentially exciting future translation that exploits the therapeutic potential of revertant keratinocytes in different forms of EB and other diseases may be to combine the natural phenomenon of revertant mosaicism with recent stem cell biology techniques, specifically in the creation of inducible pluripotent stem cells (iPSCs). This could be an extremely attractive option because it would avoid the potential genotoxic risk of retroviral vectors needed for gene therapy. Spontaneously corrected cells for iPSC generation that are derived from revertant keratinocytes avoid the need for further genetic correction. With regard to the skin, iPSCs have recently been generated from keratinocytes isolated from patients with RDEB and fibroblasts derived from individuals with Herlitz junctional EB (Bilousova et al. 2011; Itoh et al. 2011; Tolar et al. 2011, 2013). One translational vision might be to create a bank of iPSCs to differentiate into skin cells for repairing skin wounds, but there are other options. Specifically, one possibility might be to differentiate these cells into the MSCs that contain the population of epithelial progenitors recently identified in BM. These Lin $^{-} /$PDGFR $\alpha^{+}$cells could be given locally to wounded skin to augment wound healing responses. Alternatively, the cells could be given systemically and might be expected to home to areas of hypoxic skin (i.e., wounds) or reside in BM until a future episode of skin trauma occurs, at which time they would be mobilized and recruited to that damaged, hypoxic site. Clinical use of iPSCs in dermatology has not yet been achieved, but remains a future option for consideration.

\section{CONCLUDING REMARKS}

Having the capacity and technical ability to culture and expand human keratinocytes and fibroblasts has led to the widespread use of skin grafts to treat chronic wounds and ulcers in both inherited and acquired diseases. Although further refinements in bioengineering and construction of skin grafts are likely to lead to additional clinical benefits for patients, the concept and application of cell therapy for skin diseases recently has expanded to encompass other aspects of regenerative medicine. For inherited skin diseases, the potential to harness and exploit the potential of natural phenomena such as revertant mosaicism (revertant cell therapy), or the plasticity of $\mathrm{BM}$ cells to regenerate skin, provide exciting new opportunities to further develop cell therapy in dermatology. Moreover, emerging technologies such as the creation of iPSCs offer an even broader horizon to help deliver clinical benefits from regenerative medicine in dermatology. 
G. Petrof et al.

\section{ACKNOWLEDGMENTS}

The authors' own cell therapy studies in dermatology have been funded by the Dystrophic Epidermolysis Bullosa Research Association (DebRA, U.K. and Austria), The Sohana Fund, Goldman Sachs Gives, the United Kingdom (U.K.) Government Technology Strategy Board, and The Rosetrees Trust. Studies on allogeneic fibroblasts have been performed in conjunction with, but not funded by, Intercytex Ltd. The authors' research studies on cell therapy have also been supported, in part, by the U.K. National Institute for Health Research (NIHR) Biomedical Research Centre based at Guy's and St. Thomas' National Health Service (NHS) Foundation Trust and King's College London. The views expressed are those of the authors and not necessarily those of the NHS, NIHR, or Department of Health. We are also grateful for discussions and collaborations with our many national and international colleagues who share our goal of developing new cell therapies for patients in dermatology.

\section{REFERENCES}

Alexeev V, Uitto J, Igoucheva O. 2011. Gene expression signatures of mouse bone marrow-derived mesenchymal stem cells in the cutaneous environment and therapeutic implications for blistering skin disorder. Cytotherapy 13: $30-45$.

Almaani N, Nagy N, Liu L, Dopping-Hepenstal PJ, LaiCheong JE, Clements SE, Techanukul T, Tanaka A, Mellerio JE, McGrath JA. 2010. Revertant mosaicism in recessive dystrophic epidermolysis bullosa. J Invest Dermatol 130: $1840-1937$.

Alvarez-Diaz C, Cuenca-Pardo J, Sosa-Serrano A, JuarezAguilar E, Marsch-Moreno M, Kuri-Harcuch W. 2000. Controlled clinical study of deep partial thickness burns treated with frozen cultured human allogeneic epidermal sheets. J Burn Care Rehabil 21: 291-299.

Andreassi L, Pianigiani E, Andreassi A, Taddeucci P, Biagiol M. 1998. A new model of epidermal culture for the surgical treatment of vitiligo. Int Dermatol 37: 595598.

Arakawa M, Shiozuka M, Nakayama Y, Hara T, Hamada M, Kondo S, Ikeda D, Takahashi Y, Sawa R, Nonomura Y, et al. 2003. Negamycin restores dystrophin expression in skeletal and cardiac muscles of mdx mice. J Biochem 134: $751-758$.

Auger FA, Berthod F, Moulin V, Pouliot R, Germain L. 2004 Tissue-engineered skin substitutes: From in vitro constructs to in vivo applications. Biotechnol Appl Biochem 39: $263-275$.
Badiavas EV, Falanga V. 2003b. Treatment of chronic wounds with bone marrow-derived cells. Arch Dermatol 139: 510-516.

Badiavas EV, Abedi M, Butmarc J, Falanga V, Quesenberry P. 2003a. Participation of bone marrow derived cells in cutaneous wound healing. J Cell Physiol 196: 245-250.

Bey E, Prat M, Duhamel P, Benderitter M, Brachet M, Trompier F, Battaglini P, Ernou I, Boutin L, Gourven M, et al. 2010. Emerging therapy for improving wound repair of severe radiation burns using local bone marrowderived stem cell administrations. Wound Repair Regen 18: $50-58$.

Bilousova G, Chen J, Roop DR. 2011. Differentiation of mouse induced pluripotent stem cells into a multipotent keratinocyte lineage. J Invest Dermatol 131: 857-864.

Birchall N, Langdon R, Cuono C, McGuire J. 1987. Toxic epidermal necrolysis: An approach to management using cryopreserved allograft skin. J Am Acad Dermatol 16: $368-372$.

Borue X, Lee S, Grove J, Herzog EL, Harris R, Diflo T, Glusac E, Hyman K, Theise ND, Krause DS. 2004. Bone marrowderived cells contribute to epithelial engraftment during wound healing. Am J Pathol 165: 1767-1772.

Bubier JA, Sproule TJ, Alley LM, Webb CM, Fine JD, Roopenian DC, Sundberg JP. 2010. A mouse model of generalized non-Herlitz junctional epidermolysis bullosa. $J$ Invest Dermatol 130: 1819-1828.

Cardno TS, Poole ES, Mathew SF, Graves R, Tate WP. 2009. A homogeneous cell-based bicistronic fluorescence assay for high-throughput identification of drugs that perturb viral gene recoding and read-through of nonsense stop codons. RNA 15: 1614-1621.

Carsin H, Ainaud P, Le Bever H, Rives J, Lakhel A, Stephanazzi J, Lambert F, Perrot J. 2000. Cultured epithelial autografts in extensive burn coverage of severely traumatized patients: A five year single-center experience with 30 patients. Burns 26: 379-387.

Carter DM, Lin AN, Varghese MC, Caldwell D, Pratt LA, Eisinger M. 1987. Treatment of junctional epidermolysis bullosa with epidermal autografts. J Am Acad Dermatol 17: 246-250.

Chino T, Tamai K, Yamazaki T, Otsuru S, Kikuchi Y, Nimura K, Endo M, Nagai M, Uitto J, Kitajima Y, et al. 2008. Bone marrow cell transfer into fetal circulation can ameliorate genetic skin diseases by providing fibroblasts to the skin and inducing immune tolerance. Am J Pathol 173: 803814.

Conget P, Rodriguez F, Kramer S, Allers C, Simon V, Palisson F, Gonzalez S, Yubero MJ. 2010. Replenishment of type VII collagen and re-epithelialization of chronically ulcerated skin after intradermal administration of allogeneic mesenchymal stromal cells in two patients with recessive dystrophic epidermolysis bullosa. Cytotherapy 12: 429431.

Dang N, Murrell DF. 2008. Mutation analysis and characterization of COL7A1 mutations in dystrophic epidermolysis bullosa. Exp Dermatol 17: 553-568.

Dash NR, Dash SN, Routray P, Mohapatra S, Mohapatra PC. 2009. Targeting nonhealing ulcers of lower extremity in human through autologous bone marrow-derived mesenchymal stem cells. Rejuvenation Res 12: 359-366. 
de la Portilla F, Alba F, Garcia-Olmo D, Herrerias JM, Gonzalez FX, Galindo A. 2012. Expanded allogeneic adiposederived stem cells (eASCs) for the treatment of complex perianal fistula in Crohn's disease: Results from a multicenter phase I/IIa clinical trial. Int J Colorectal Dis 28: 313-323.

De Luca M, Albanese E, Bondanza S, Megna M, Ugozzoli L, Molina F, Cancedda R, Santi PL, Bormioli M, Stella M, et al. 1989. Multicentre experience in the treatment of burns with autologous and allogenic cultured epithelium, fresh or preserved in a frozen state. Burns 15: 303-309.

De Luca M, Albanese E, Cancedda R, Viacava A, Faggioni A, Zambruno G, Giannetti A. 1992. Treatment of leg ulcers with cryopreserved allogeneic cultured epithelium. A multicenter study. Arch Dermatol 128: 633-638.

Eca LP, Pinto DG, de Pinho AM, Mazzetti MP, Odo ME. 2012. Autologous fibroblast culture in the repair of aging skin. Dermatol Surg 38: 180-184.

Eisenberg M, Llewelyn D. 1998. Surgical management of hands in children with recessive dystrophic epidermolysis bullosa: Use of allogeneic composite cultured skin grafts. Brit J Plast Surg 51: 608-613.

Falanga V, Iwamoto S, Chartier M, Yufit T, Butmarc J, Kouttab N, Shrayer D, Carson P. 2007. Autologous bone marrow-derived cultured mesenchymal stem cells delivered in a fibrin spray accelerate healing in murine and human cutaneous wounds. Tissue Eng 13: 1299-1312.

Fathke C, Wilson L, Hutter J, Kapoor V, Smith A, Hocking A, Isik F. 2004. Contribution of bone marrow-derived cells to skin: Collagen deposition and wound repair. Stem Cells 22: $812-822$.

Fine JD, Mellerio JE. 2009a. Extracutaneous manifestations and complications of inherited epidermolysis bullosa: Part I. Epithelial associated tissues. J Am Acad Dermatol 61: 367-384.

Fine JD, Mellerio JE. 2009b. Extracutaneous manifestations and complications of inherited epidermolysis bullosa: Part II. Other organs. J Am Acad Dermatol 61: 387-402.

Fine JD, Eady RA, Bauer EA, Bauer JW, Bruckner-Tuderman L, Heagerty A, Hintner H, Hovnanian A, Jonkman MF Leigh I, et al. 2008. The classification of inherited epidermolysis bullosa (EB): Report of the Third International Consensus Meeting on Diagnosis and Classification of EB. J Am Acad Dermatol 58: 931-950.

Fritsch A, Loeckermann S, Kern JS, Braun A, Bosl MR, Bley TA, Schumann H, von Elverfeldt D, Paul D, Erlacher M, et al. 2008. A hypomorphic mouse model of dystrophic epidermolysis bullosa reveals mechanisms of disease and response to fibroblast therapy. J Clin Invest 118: 1669-1679.

Fujita Y, Abe R, Inokuma D, Sasaki M, Hoshina D, Natsuga K, Nishie W, McMillan JR, Nakamura H, Shimizu T, et al. 2010. Bone marrow transplantation restores epidermal basement membrane protein expression and rescues epidermolysis bullosa model mice. Proc Natl Acad Sci 107: $14345-14350$.

Gallico GG III, O'Connor NE, Compton CC, Kehinde O, Green H. 1984. Permanent coverage of large burn wounds with autologous cultured human epithelium. $N$ Engl J Med 311: 448-451.

Gluckman E, Broxmeyer HA, Auerbach AD, Friedman HS, Douglas GW, Devergie A, Esperou H, Thierry D, Socie G,
Lehn P, et al. 1989. Hematopoietic reconstruction in a patient with Fanconi's anaemia by means of umbilical/ cord blood from an HLA-identical sibling. N Engl J Med 321: $1174-1178$

Gostynski A, Deviaene FC, Pasmooij AM, Pas HH, Jonkman MF. 2009. Adhesive stripping to remove epidermis in junctional epidermolysis bullosa for revertant cell therapy. Br J Dermatol 161: 444-447.

Goto M, Sawamura D, Ito K, Abe M, Nishie W, Sakai K, Shibaki A, Akiyama M, Shimizu H. 2006. Fibroblasts show more potential as target cells than keratinocytes in COL7A1 gene therapy of dystrophic epidermolysis bullosa. J Invest Dermatol 126: 766-772.

Gravante G, Di Fede MC, Araco A, Grimaldi M, De Angelis B, Arpino A, Cervelli V, Montone A. 2007. A randomized trial comparing ReCell system of epidermal cells delivery versus classic skin grafts for the treatment of deep partial thickness burns. Burns 33: 966-972.

Green H, Kehinde O, Thomas J. 1979. Growth of cultured human epidermal cells into multiple epithelia suitable for grafting. Proc Natl Acad Sci 76: 5665-5668.

Grove JE, Bruscia E, Krause DS. 2004. Plasticity of bone marrow-derived stem cells. Stem Cells 22: 487-500.

Guerid S, Darwiche SE, Berger MM, Applegate LA, Benathan M, Raffoul W. 2013. Autologous keratinocyte suspension in platelet concentrate accelerates and enhances wound healing-A prospective randomized clinical trial on skin graft donor sites: Platelet concentrate and keratinocytes on donor sites. Fibrogenesis Tissue Repair 6: 8.

Hasegawa T, Suga Y, Mizoguchi M, Ikeda S, Ogawa H, Kubo K, Matsui H, Kagawa S, Kuroyanagi Y. 2004. Clinical trial of allogeneic cultured dermal substitute for the treatment of intractable skin ulcers in 3 patients with recessive dystrophic epidermolysis bullosa. J Am Acad Dermatol 50: 803-804.

Hasegawa T, Suga Y, Mizoguchi M, Muramatsu S, Mizuno Y, Haruna K, Ikeda S, Kuroyanagi Y, Ogawa H. 2007. Intractable venous leg ulcer treated successfully with allogeneic cultured dermal substitute. Scand J Plast Reconstr Surg Hand Surg 41: 326-328.

Hefton JM, Madden MR, Finkelstein JL, Shires GT. 1983. Grafting of burn patients with allografts of cultured epidermal cells. Lancet 2: 428-430.

Heinonen S, Mannikko M, Klement JF, Whitaker-Menezes D, Murphy GF, Uitto J. 1999. Targeted inactivation of the type VII collagen gene (Col7a1) in mice results in severe blistering phenotype: A model for recessive dystrophic epidermolysis bullosa. J Cell Sci 112: 3641-3648.

Hill JC, Grimwood RE, Parsons DS. 1992. Treatment of chronic erosions of junctional epidermolysis bullosa with human epidermal allografts. J Derm Surg Oncol 18: $396-400$.

Humpert PM, Bartsch U, Konrade I, Hammes HP, Morcos M, Kasper M, Bierhaus A, Nawroth PP. 2005. Locally applied mononuclear bone marrow cells restore angiogenesis and promote wound healing in a type 2 diabetic patient. Exp Clin Endocrinol Diabetes 113: 538-540.

Ishii G, Sangai T, Sugiyama K, Ito T, Hasebe T, Endoh Y, Magae J, Ochiai A. 2005. In vivo characterization of bone marrow-derived fibroblasts recruited into fibrotic lesions. Stem Cells 23: 699-706. 
G. Petrof et al.

Ito K, Sawamura D, Goto M, Nakamura H, Nishie W, Saka K, Natsuga K, Shinkuma S, Shibaki A, Uitto J, et al. 2009. Keratinocyte-/fibroblast-targeted rescue of Col7al-disrupted mice and generation of an exact dystrophic epidermolysis bullosa model using a human COL7A1 mutation. Am J Pathol 175: 2508-2517.

Itoh M, Kiuru M, Cairo MS, Christiano AM. 2011. Generation of keratinocytes from normal and recessive dystrophic epidermolysis bullosa-induced pluripotent stem cells. Proc Natl Acad Sci 108: 8797-8802.

Jongmans MC, Verwiel ET, Heijdra Y, Vulliamy T, Kamping EJ, Hehir-Kwa JY, Bongers EM, Pfundt R, van Emst L, van Leeuwen FN, et al. 2012. Revertant somatic mosaicism by mitotic recombination in dyskeratosis congenita. Am J Hum Genet 90: 426-433.

Jonkman MF, Scheffer H, Stulp R, Pas HH, Nijenhuis M, Heeres K, Owaribe K, Pulkkinen L, Uitto J. 1997. Revertant mosaicism in epidermolysis bullosa caused by mitotic gene conversion. Cell 88: 543-551.

Kern JS, Loeckermann S, Fritsch A, Hausser I, Roth W, Magin TM, Mack C, Muller ML, Paul O, Ruther P, et al. 2009. Mechanisms of fibroblast cell therapy for dystrophic epidermolysis bullosa: High stability of collagen VII favors long-term skin integrity. Mol Ther 17: 1605-1615.

Kirsner RS, Marston WA, Snyder RJ, Lee TD, Cargill DI, Slade HB. 2012. Spray-applied cell therapy with human allogeneic fibroblasts and keratinocytes for the treatment of chronic venous leg ulcers: A phase 2, multicentre, double-blind, randomised, placebo-controlled trial. Lancet 380: 977-985.

Kopp J, Horch RE, Stachel KD, Holter W, Kandler MA, Hertzberg H, Rascher W, Campean V, Carbon R, Schneider H. 2005. Hematopoietic stem cell transplantation and subsequent $80 \%$ skin exchange by grafts from the same donor in a patient with Herlitz disease. Transplantation 79: 255-256.

Korbling M, Katz RL, Khanna A, Ruifrok AC, Rondon G, Albitar M, Champlin RE, Estrov Z. 2002. Hepatocytes and epithelial cells of donor origin in recipients of peripheral-blood stem cells. N Engl J Med 346: 738-746.

Krause DS, Theise ND, Collector MI, Henegariu O, Hwang S, Gardner R, Neutzel S, Sharkis SJ. 2001. Multi-organ, multi-lineage engraftment by a single bone marrow-derived stem cell. Cell 105: 369-377.

Kumagai N, Oshima H, Tanabe M, Ishida H. 1997. Treatment of giant congenital nevi with cryopreserved allogeneic skin and fresh autologous cultured epithelium. Ann Plast Surg 39: 483-488.

Lai-Cheong JE, McGrath JA. 2013. Revertant mosaicism in the skin. G Ital Dermatol Venereol 148: 73-82.

Lai-Cheong JE, McGrath JA, Uitto J. 2011. Revertant mosaicism in skin: Natural gene therapy. Trends Mol Med 17: $140-148$.

Lataillade JJ, Doucet C, Bey E, Carsin H, Huet C, Clairand I, Bottollier-Depois JF, Chapel A, Ernou I, Gourven M, et al. 2007. New approach to radiation burn treatment by dosimetry-guided surgery combined with autologous mesenchymal stem cell therapy. Regen Med 2: 785-794.

Lee H. 2012. Outcomes of sprayed cultured epithelial autografts for full-thickness wounds: A single-centre experience. Burns 38: 931-936.
Liao Y, Itoh $\mathrm{M}$, Yang A, Zhu $\mathrm{H}$, Roberts $\mathrm{S}$, Highet AM, Latshaw S, Mitchell K, van de Ven C, Christiano A, et al. 2013. Human cord blood derived unrestricted somatic stem cells promote wound healing and have therapeutic potential for patients with recessive dystrophic epidermolysis bullosa. Cell Transplant 23: 303-317.

Lowe NJ, Lowe PL, St Clair Roberts J. 2010. A phase IIa open-label dose-escalation pilot study using allogeneic human dermal fibroblasts for nasolabial folds. Dermatologic Surg 36: 1578-1585.

Lu D, Chen B, Liang Z, Deng W, Jiang Y, Li S, Xu J, Wu Q, Zhang Z, Xie B, et al. 2011. Comparison of bone marrow mesenchymal stem cells with bone marrow-derived mononuclear cells for treatment of diabetic critical limb ischemia and foot ulcer: A double-blind, randomized, controlled trial. Diabetes Res Clin Pract 92: 26-36.

Madden MR, Finkelstein JL, Staiano-Coico L, Goodwin CW, Shires GT, Nolan EE, Hefton JM. 1986. Grafting of cultured allogeneic epidermis on second- and third-degree burn wounds on 26 patients. J Trauma 26: 955-962.

Matsuzaki K, Kumagai N. 2013. Treatment of vitiligo with autologous cultured keratinocytes in 27 cases. Eur J Plast Surg 36: 651-656.

Mavilio F, Pellegrini G, Ferrari S, Di Nunzio F, Di Iorio E, Recchia A, Maruggi G, Ferrari G, Provasi E, Bonini C, et al. 2006. Correction of junctional epidermolysis bullosa by transplantation of genetically modified epidermal stem cells. Nat Med 12: 1397-1402.

McGrath JA, Schofield OM, Ishida-Yamamoto A, O'Grady A, Mayou BJ, Navsaria H, Leigh IM, Eady RA. 1993. Cultured keratinocyte allografts and wound healing in severe recessive dystrophic epidermolysis bullosa. J Am Acad Dermatol 29: 407-419.

McGuire J, Birchall N, Cuono C, Moellman G, Kuklinska E, Langdon R. 1987. Successful engraftment of allogeneic keratinocyte cultures in recessive dystrophic epidermolysis bullosa. J Invest Dermatol 88: 506.

Milner SM, Cordova AC, Leffell M, Price LA. 2011. Cultured epithelial allograft for the management of cutaneous graft-versus-host disease following stem-cell transplantation. Transplantation 92: e53-e54.

Moravvej H, Hormozi AK, Hosseini SN, Sorouri R, Mozafari N, Ghazisaidi MR, Rad MM, Moghimi MH, Sadeghi SM, Mirzadeh H. 2012. Comparison of the application of allogeneic fibroblast and autologous mesh grafting with the conventional method in the treatment of third-degree burns. J Burn Care Res doi: 10.1097/ BCR.0b013e31825aeac1.

Morimoto N, Ito T, Takemoto S, Katakami M, Kanda N, Tada H, Tanaka S, Teramukai S, Kawai K, Nakamura Y, et al. 2012. An exploratory clinical study on the safety and efficacy of an autologous fibroblast-seeded artificial skin cultured with animal product-free medium in patients with diabetic foot ulcers. Int Wound J doi: 10.1111/ j.1742-481X.2012.01064.x.

Moroi Y, Fujita S, Fukagawa S, Mashino T, Goto T, Masuda T, Urabe K, Kubo K, Matsui H, Kagawa S, et al. 2004. Clinical evaluation of allogeneic cultured dermal substitutes for intractable skin ulcers after tumor resection. Eur J Dermatol 14: 172-176.

Mulekar SV. 2004. Long-term follow-up study of segmental and focal vitiligo treated by autologous, noncultured me- 
lanocyte-keratinocyte cell transplantation. Arch Dermatol 140: $1211-1215$.

Mulekar SV, Al Issa A, Al Eisa A, Asaad M. 2005. Genital vitiligo treated by autologous, noncultured melanocytekeratinocyte cell transplantation. Dermatol Surg 31: 1737-1739; discussion 1740.

Nagy N, Almaani N, Tanaka A, Lai-Cheong JE, Techanukul T, Mellerio JE, McGrath JA. 2011. HB-EGF induces COL7A1 expression in keratinocytes and fibroblasts: Possible mechanism underlying allogeneic fibroblast therapy in recessive dystrophic epidermolysis Bullosa. J Invest Dermatol 131: 1771-1774.

Nilforoushzadeh MA, Siadat AH, Arianrad M, Moulavi F, Baradaran EH, Esfahani MH. 2010. Soft tissue augmentation by autologous cultured fibroblasts transplantation for treatment of wrinkles and scars: A case series of 20 patients. J Res Med Sci 15: 167-171.

Nishimoto J, Amoh Y, Tanabe K, Niiyama N, Katsuoka K, Kuroyanagi Y. 2007. Intractable leg ulcers associated with antiphospholipid syndrome with stasis dermatitis: Treatment with allogeneic cultured dermal substitute. Eur J Dermatol 17: 350-351.

O'Connor N, Mulliken JB, Banks-Schlegel S, Kehinde O, Green H. 1981. Grafting of burns with cultured epithelium prepared from autologous epidermal cells. Lancet 317: $75-78$.

Odessey R. 1992. Addendum: Multicenter experience with cultured epidermal autograft for treatment of burns. $J$ Burn Care Rehabil 13: 174-180.

Ohtani T, Okamoto K, Kaminaka C, Kishi T, Sakurane M, Yamamoto Y, Uede K, Kubo K, Kuroyanagi Y, Furukawa F. 2004. Digital gangrene associated with idiopathic hypereosinophilia: Treatment with allogeneic cultured dermal substitute (CDS). Eur J Dermatol 14: 168-171.

Ojeh NO, Frame JD, Navsaria HA. 2001. In vitro characterization of an artificial dermal scaffold. Tissue Eng 7: 457472.

Olsson MJ, Juhlin L. 1998. Leucoderma treated by transplantation of a basal cell layer enriched suspension. $\mathrm{Br} \mathrm{J}$ Dermatol 138: 644-648.

Ortiz-Urda S, Lin Q, Green CL, Keene DR, Marinkovich MP, Khavari PA. 2003. Injection of genetically engineered fibroblasts corrects regenerated human epidermolysis bullosa skin tissue. J Clin Invest 111: 251-255.

Palazzi X, Marchal T, Chabanne L, Spadafora A, Magnol JP, Meneguzzi G. 2000. Inherited dystrophic epidermolysis bullosa in inbred dogs: A spontaneous animal model for somatic gene therapy. J Invest Dermatol 115: 135-137.

Pasmooij AM, Jonkman MF, Uitto J. 2012. Revertant mosaicism in heritable skin diseases: Mechanisms of natural gene therapy. Discov Med 14: 167-179.

PetrofG, Martinez-Queipo M, Mellerio JE, Kemp P, McGrath JA. 2013. Fibroblast cell therapy enhances initial healing in recessive dystrophic epidermolysis bullosa wounds: Results of a randomized, vehicle-controlled trial. $\mathrm{Br}$ J Dermatol 169: 1025-1033.

Plott RT, Brysk MM, Newton RC, Raimer SS, Rajaraman S. 1989. A surgical treatment for vitiligo: Autologous cultured-epithelial grafts. J Dermatol Surg Oncol 15: 11611166.
Rasulov MF, Vasilchenkov AV, Onishchenko NA, Krasheninnikov ME, Kravchenko VI, Gorshenin TL, Pidtsan RE, Potapov IV. 2005. First experience of the use bone marrow mesenchymal stem cells for the treatment of a patient with deep skin burns. Bull Exp Biol Med 139: 141-144.

Ravari H, Hamidi-Almadari D, Salimifar M, Bonakdaran S, Parizadeh MR, Koliakos G. 2011. Treatment of non-healing wounds with autologous bone marrow cells, platelets, fibrin glue and collagen matrix. Cytotherapy 13: $705-$ 711.

Regauer S, Seiler GR, Barrandon Y, Easley KW, Compton CC. 1990. Epithelial origin of cutaneous anchoring fibrils. J Cell Biol 111: 2109-2115.

Remington J, Wang X, Hou Y, Zhou H, Burnett J, Muirhead T, Uitto J, Keene DR, Woodley DT, Chen M. 2009. Injection of recombinant human type VII collagen corrects the disease phenotype in a murine model of dystrophic epidermolysis bullosa. Mol Ther 17: 26-33.

Rheinwald JG, Green H. 1975. Serial cultivation of strains of human epidermal keratinocytes: The formation of keratinizing colonies from single cells. Cell 6: 331-343.

Rivas-Torres MT, Amato D, Arambula-Alvarez H, Kuri-Harcuch W. 1996. Controlled clinical study of skin donor sites and deep partial-thickness burns treated with cultured epidermal allografts. Plast Reconstr Surg 98: 279_ 287.

Roseeuw D, De Raeve L, Dangoisse C, Ramet J. 1994. Treatment of epidermolysis bullosa with human cultured epidermal allografts. Dermatology 189 Suppl 2: 68-70.

Rowe SM, Clancy JP. 2009. Pharmaceuticals targeting nonsense mutations in genetic diseases: Progress in development. BioDrugs 23: 165-174.

Ryynanen J, Sollberg S, Parente MG, Chung LC, Christiano AM, Uitto J. 1992. Type VII collagen gene expression by cultured human cells and in fetal skin. Abundant mRNA and protein levels in epidermal keratinocytes. JClin Invest 89: $163-168$.

Sasaki M, Abe R, Fujita Y, Ando S, Inokuma D, Shimizu H. 2008. Mesenchymal stem cells are recruited into wounded skin and contribute to wound repair by transdifferentiation into multiple skin cell type. J Immunol 180: 2581-2587.

Schofield OMV, Cassella JP, Navsaria HA, Leigh IM, Mayou BJ, Eady RAJ. 1990. Cultured keratinocyte allografts in dystrophic epidermolysis bullosa: Preliminary observations. Br J Dermatol 123: 66-67.

Shin KC, Park BY, Kim HK, Kim WS, Bae TH. 2011. The use of cultured allogenic keratinocyte grafting in a patient with epidermolysis bullosa simplex. Ann Dermatol 23: S393-S397.

Shirakata Y, Kimura R, Nanba D, Iwamoto R, Tokumaru S, Morimoto C, Yokota K, Nakamura M, Sayama K, Mekada E, et al. 2005. Heparin-binding EGF-like growth factor accelerates keratinocyte migration and skin wound healing. J Cell Sci 118: 2363-2370.

Smith SR, Munavalli G, Weiss R, Maslowski JM, Hennegan KP, Novak JM. 2012. A multicenter, double-blind, placebo-controlled trial of autologous fibroblast therapy for the treatment of nasolabial fold wrinkles. Dermatol Surg 38: $1234-1243$.

Sood R, Roggy D, Zieger M, Balledux J, Chaudhari S, Koumanis DJ, Mir HS, Cohen A, Knipe C, Gabehart K, et al. 
G. Petrof et al.

2010. Cultured epithelial autografts for coverage of large burn wounds in eighty-eight patients: The Indiana University experience. J Burn Care Res 31: 559-568.

Stanley JR, Rubinstein N, Klaus-Kovtun V. 1985. Epidermolysis bullosa acquisita antigen is synthesized by both human keratinocytes and human dermal fibroblasts. $J$ Invest Dermatol 85: 542-545.

Tamai K, Yamazaki T, Chino T, Ishii M, Otsuru S, Kikuchi Y, Iinuma S, Saga K, Nimura K, Shimbo T, et al. 2011. PDGFR $\alpha$-positive cells in bone marrow are mobilized by high mobility group box 1 (HMGB1) to regenerate injured epithelia. Proc Natl Acad Sci 108: 6609-6614.

Teepe RG, Kreis RW, Koebrugge EJ, Kempenaar JA, Vloemans AF, Hermans RP, Boxma H, Dokter J, Hermans J, Ponec M, et al. 1990. The use of cultured autologous epidermis in the treatment of extensive burn wounds. $J$ Trauma 30: 269-275.

Teepe RG, Roseeuw DI, Hermans J, Koebrugge EJ, Altena T, de Coninck A, Ponec M, Vermeer BJ. 1993. Randomized trial comparing cryopreserved cultured epidermal allografts with hydrocolloid dressings in healing chronic venous ulcers. J Am Acad Dermatol 29: 982-988.

Tolar J, Ishida-Yamamoto A, Riddle M, McElmurry RT, Osborn M, Xia L, Lund T, Slattery C, Uitto J, Christiano AM, et al. 2009. Amelioration of epidermolysis bullosa by transfer of wild-type bone marrow cells. Blood 113: $1167-1174$.

Tolar J, Xia L, Riddle MJ, Lees CJ, Eide CR, McElmurry RT, Titeux M, Osborn MJ, Lund TC, Hovnanian A, et al. 2011. Induced pluripotent stem cells from individuals with recessive dystrophic epidermolysis bullosa. J Invest Dermatol 131: 848-856.

Tolar J, Mehta PA, Walters MC. 2012a. Hematopoietic cell transplantation for nonmalignant disorders. Biol Blood Marrow Transplant 18: S166-S171.

Tolar J, McGrath JA, Keene DR, Hook K, Osborn MJ, Riddle MJ, Kavand S, Hordinsky M, Woodley D, Chen M, et al. 2012b. Hematopoietic and mesenchymal cell transplantation after myeloablative and non-myeloablative conditioning for recessive dystrophic and junctional epidermolysis bullosa (RDEB, JEB). Society of Investigative Dermatology, Venice, Italy. J Invest Dermatol 132: A534.

Tolar J, McGrath JA, Keene DR, Hook K, Osborn MJ, Riddle MJ, Kavand S, Hordinsky M, Woodley D, Chen M, et al. 2012c. Hematopoietic and mesenchymal cell transplantation after myeloablative and non-myeloablative conditioning for recessive dystrophic and junctional epidermolysis bullosa (RDEB, JEB). J Invest Dermatol 132: S91.

Tolar J, Xia L, Lees CJ, Riddle M, McElroy A, Keene DR, Lund TC, Osborn MJ, Marinkovich MP, Blazar BR, et al. 2013. Keratinocytes from induced pluriptent stem cells in junctional epidermolysis bullosa. J Invest Dermatol 133: 562-565.

Toossi P, Shahidi-Dadras M, Mahmoudi Rad M, Fesharaki RJ. 2011. Non-cultured melanocyte-keratinocyte transplantation for the treatment of vitiligo: A clinical trial in an Iranian population. J Eur Acad Dermatol Venereol 25: 1182-1186.

Uitto J, Christiano AM, McLean WH, McGrath JA. 2012. Novel molecular therapies for heritable skin disorders. $J$ Invest Dermatol 132: 820-828.
Vazquez-Martinez OT, Martinez-Rodriguez HG, VelasquezArenas L, Banos-Gonzalez D, Ortiz-Lopez R, Padilla-Rivas G, Welsh O, Ocampo-Candiani J. 2011. Treatment of vitiligo with a melanocyte-keratinocyte cell suspension versus dermabrasion only: A pilot study with a 12-month follow up. J Drugs Dermatol 10: 1032-1036.

Venugopal SS, Yan W, Frew JW, Cohn HI, Rhodes LM, Tran K, Melbourne W, Nelson JA, Sturm M, Fogarty J, et al. 2013. A phase II randomized vehicle-controlled tiral of allogeneic fibroblasts for recessive dystrophic epidermolysis bullosa. J Am Acad Dermatol 10: 898-908.

Verplancke P, Beele H, Monstrey S, Naeyaert JM. 1997. Treatment of dystrophic epidermolysis bullosa with autologous meshed split-thickness skin grafts and allogeneic cultured keratinocytes. Dermatology 194: 380-382.

Wagner JE, Ishida-Yamamoto A, McGrath JA, Hordinsky M, Keene DR, Woodley DT, Chen M, Riddle MJ, Osborn MJ, Lund T, et al. 2010. Bone marrow transplantation for recessive dystrophic epidermolysis bullosa. $N$ Engl J Med 363: 629-639.

Wakao S, Kitada M, Kuroda Y, Shigemoto T, Matsuse D, Akashi H, Tanimura Y, Tsuchiyama K, Kikuchi T, Goda M, et al. 2011. Multilineage-differentiating stress-enduring (Muse) cells are a primary source of induced pluripotent stem cells in human fibroblasts. Proc Natl Acad Sci 108: $9875-9880$.

Watson D, Keller GS, Lacombe V, Fodor PB, Rawnsley J, Lask GP. 1999. Autologous fibroblasts for treatment of facial rhytids and dermal depressions. A pilot study. Arch Facial Plast Surg 1: 165-170.

Weiss RA, Weiss MA, Beasley KL, Munavalli G. 2007. Autologous cultured fibroblast injection for facial contour deformities: A prospective, placebo-controlled, phase III clinical trial. Dermatol Surg 33: 263-268.

Wong T, Gammon L, Liu L, Mellerio JE, Dopping-Hepenstal PJ, Pacy J, Elia G, Jeffery R, Leigh IM, Navsaria H, et al. 2008. Potential of fibroblast cell therapy for recessive dystrophic epidermolysis bullosa. J Invest Dermatol 128: 2179-2189.

Wood FM, Kolybaba ML, Allen P. 2006. The use of cultured epithelial autograft in the treatment of major burn wounds: Eleven years of clinical experience. Burns 32: $538-544$.

Woodley DT, Briggaman RA, Gammon WR, O’Keefe EJ. 1985. Epidermolysis bullosa acquisita antigen is synthesized by human keratinocytes cultured in serum-free medium. Biochem Biophys Res Commun 130: 1267-1272.

Woodley DT, Krueger GG, Jorgensen CM, Fairley JA, Atha T, Huang Y, Chan L, Keene DR, Chen M. 2003. Normal and gene-corrected dystrophic epidermolysis bullosa fibroblasts alone can produce type VII collagen at the basement membrane zone. J Invest Dermatol 121: 1021-1028.

Woodley DT, Remington J, Huang Y, Hou Y, Li W, Keene DR, Chen M. 2007. Intravenously injected human fibroblasts home to skin wounds, deliver type VII collagen, and promote wound healing. Mol Ther 15: 628-635.

Woodley DT, Wang X, Amir M, Hwang B, Remington J, Hou Y, Uitto J, Keene D, Chen M. 2013. Intravenously injected recombinant human type vii collagen homes to skin wounds and restores skin integrity of dystrophic epidermolysis bullosa. J Invest Dermatol 133: 1910-1913. 
Xu Y, Huang S, Fu X. 2012. Autologous transplantation of bone marrow-derived mesenchymal stem cells: A promising therapeutic strategy for prevention of skin-graft contraction. Clin Exp Dermatol 37: 497-500.

Yamada N, Uchinuma E, Kuroyanagi Y. 2008a. Clinical trial of allogeneic cultured dermal substitutes for intractable skin ulcers of the lower leg. J Artif Organs 11: 100-103.

Yamada N, Uchinuma E, Matsumoto Y, Kuroyanagi Y. 2008b. Comparative evaluation of re-epithelialization promoted by fresh or cryopreserved cultured dermal substitute. J Artif Organs 11: 221-224.

Yanaga H, Udoh Y, Yamauchi T, Yamamoto M, Kiyokawa K, Inoue Y, Tai Y. 2001. Cryopreserved cultured epidermal allografts achieved early closure of wounds and reduced scar formation in deep partial-thickness burn wounds (DDB) and split-thickness skin donor sites of pediatric patients. Burns 27: 689-698.
Yonezawa $\mathrm{M}$, Tanizaki $\mathrm{H}$, Inoguchi $\mathrm{N}$, Ishida $\mathrm{M}$, Katoh $\mathrm{M}$, Tachibana T, Miyachi Y, Kubo K, Kuroyanagi Y. 2007. Clinical study with allogeneic cultured dermal substitutes for chronic leg ulcers. Int J Dermatol 46: 36-42.

Yoshikawa T, Mitsuno H, Nonaka I, Sen Y, Kawanishi K, Inada Y, Takakura Y, Okuchi K, Nonomura A. 2008. Wound therapy by marrow mesenchymal cell transplantation. Plast Reconstr Surg 121: 860-877.

Zenz R, Scheuch H, Martin P, Frank C, Eferl R, Kenner L, Sibilia M, Wagner EF. 2003. c-Jun regulates eyelid closure and skin tumor development through EGFR signaling. Dev Cell 4: 879-889.

Zhou H, Guo M, Bian C, Sun Z, Yang Z, Zeng Y, Ai H, Zhao RC. 2010. Efficacy of bone marrow-derived mesenchymal stem cells in the treatment of sclerodermatous chronic graft-versus-host disease: Clinical report. Biol Blood Marrow Transplant 16: 403-412. 


\section{$\&_{\mathrm{CSH}}^{\infty} \&$ Cold Spring Harbor

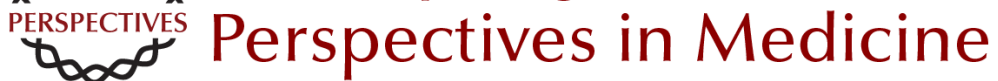

\section{Cell Therapy in Dermatology}

Gabriela Petrof, Alya Abdul-Wahab and John A. McGrath

Cold Spring Harb Perspect Med 2014; doi: 10.1101/cshperspect.a015156

Subject Collection The Skin and Its Diseases

Melanoma: Clinical Features and Genomic Insights

Elena B. Hawryluk and Hensin Tsao

Wound Healing and Skin Regeneration

Makoto Takeo, Wendy Lee and Mayumi Ito

The Dermal Papilla: An Instructive Niche for

Epithelial Stem and Progenitor Cells in

Development and Regeneration of the Hair Follicle Bruce A. Morgan

Immunology and Skin in Health and Disease

Jillian M. Richmond and John E. Harris

Desmosomes: Regulators of Cellular Signaling and Adhesion in Epidermal Health and Disease Jodi L. Johnson, Nicole A. Najor and Kathleen J. Green

Markers of Epidermal Stem Cell Subpopulations in Adult Mammalian Skin Kai Kretzschmar and Fiona M. Watt

Psoriasis

Paola Di Meglio, Federica Villanova and Frank O. Nestle

Cell Therapy in Dermatology Gabriela Petrof, Alya Abdul-Wahab and John A. McGrath
Modeling Cutaneous Squamous Carcinoma

Development in the Mouse

Phillips Y. Huang and Allan Balmain

Natural and Sun-Induced Aging of Human Skin Laure Rittié and Gary J. Fisher

Advanced Treatment for Basal Cell Carcinomas Scott X. Atwood, Ramon J. Whitson and Anthony E. Oro

Epidermal Polarity Genes in Health and Disease Frederik Tellkamp, Susanne Vorhagen and Carien M. Niessen

Induced Pluripotent Stem Cells in Dermatology:

Potentials, Advances, and Limitations Ganna Bilousova and Dennis R. Roop

The Genetics of Human Skin Disease Gina M. DeStefano and Angela M. Christiano

p53/p63/p73 in the Epidermis in Health and Disease

Vladimir A. Botchkarev and Elsa R. Flores

Diversification and Specialization of Touch

Receptors in Skin

David M. Owens and Ellen A. Lumpkin

For additional articles in this collection, see http://perspectivesinmedicine.cshlp.org/cgi/collection/ 